\title{
Improved trawl selectivity: effects on the ecosystem in the South Catalan Sea (NW Mediterranean)
}

\author{
Marta Coll ${ }^{1, *}$, Nixon Bahamon ${ }^{1}$, Francesc Sardà ${ }^{1}$, Isabel Palomera ${ }^{1}$, Sergi Tudela ${ }^{2}$, \\ Petri Suuronen ${ }^{3}$
}

\author{
${ }^{1}$ Institut de Ciències del Mar (ICM-CSIC), Passeig Marítim de la Barceloneta 37-49, 08003 Barcelona, Spain \\ ${ }^{2}$ WWF Mediterranean Programme Office, Canuda 37, 08002 Barcelona, Spain \\ ${ }^{3}$ Finnish Game and Fisheries Research Institute, PO Box 2, 00791 Helsinki, Finland
}

\begin{abstract}
We explored the potential ecosystem effects of improved selectivity in the South Catalan Sea demersal trawl fishery. A calibrated food web model representing current conditions of the ecosystem and selectivity data from recent fishing experiments were used to perform temporal dynamic simulations. This enabled the evaluation of direct and indirect impacts of fishing and provided insights into the sustainability of various management options for the trawl fishery. This fishery has the biggest fleet in the area, it is highly multispecies, and catches are largely composed of juveniles of target species and non-target species, which are often discarded in large quantities. Simulations indicate that improvement of trawl selectivity would have noticeable and complex direct and indirect effects on target and non-target demersal species. The biomass and catch of various commercial species (e.g. anglerfish, adult hake) would increase, while that of invertebrates (e.g. suprabenthos, Norway lobster) and juvenile and small-sized fish species (e.g. juvenile hake, blue whiting) would decrease due to higher predation mortalities and trophic cascades in the food web. Impacts on the pelagic compartment would also be noticeable. A slight increase in the mean trophic level of the community and of the catch is predicted, as well as of ecosystem biomass diversity. Generally, however, a greater reduction of fishing effort would be necessary for the recovery of highly exploited or overexploited demersal species. Trawling would experience moderate decreases in catches, while long-lining and bait-trolling would benefit. This work highlights the importance of including the mortality incurred during or post-escape from trawl nets when assessing the ecosystem effects of improved trawl selectivity.
\end{abstract}

KEY WORDS: Trawl selectivity - Ecosystem management of fisheries · Trophodynamic model · Ecopath with Ecosim $\cdot$ Mediterranean Sea

Resale or republication not permitted without written consent of the publisher

\section{INTRODUCTION}

Although the impacts of increased bottom trawl selectivity on commercial species have been investigated to some extent (e.g. Bahamon et al. 2007a), there is a high uncertainty regarding the effects of selectivity within the ecosystem. Fishing has direct and indirect impacts in the food web (Pace et al. 1999, Jennings et al. 2002), and predation mortality is of great importance in marine environments, as well as in highly fished ecosystems (Bax 1991). Moreover, improving trawl selectivity by increasing mesh size or by chang- ing the mesh configuration in the cod end will reduce fishing-induced mortality only if the majority of escaping fish survives. If the survival of escapees is low, there may be no advantage to increasing the selectivity of trawl gear, and derived management options could produce negative impacts due to the underestimation of the overall fishing mortality (Suuronen 2005). Escape mortality varies among species, fish size, and environmental conditions, and can be immediate or delayed due to skin or internal organ damage, or to higher predation vulnerability (e.g. Suuronen et al. 1996a, 2005). 
Demersal marine resources on the continental shelves and upper slopes in the NW Mediterranean Sea are mainly caught by bottom-trawling and are fully exploited or overexploited (Aldebert \& Recasens 1996, Sardà et al. 2005). Trawling fleets in the area have developed toward an industrial type of activity with constantly increasing fishing capacity. Catches are mainly composed of juveniles of target species accompanied by substantial amounts of non-target species that are often discarded (Sardà et al. 2005). In addition, bottom-trawling has a wide impact on all exploitable trophic levels (TLs; from TL 2 to 5) of the ecosystem in the Catalan and Adriatic Seas, impacting target and non-target species; some of these impacts are major (Coll et al. 2006, 2007).

Experiments aimed at improving selectivity of bottom-trawling by shifting from the current $40 \mathrm{~mm}$ diamond mesh cod end (DM) to $40 \mathrm{~mm}$ square mesh cod end (SM) and/or sorting grids with $20 \mathrm{~mm}$ bar-spacing (SG) have been conducted in the South Catalan Sea (NW Mediterranean) since the early 2000s (Sardà et al. 2005, 2006, Bahamon et al. 2006). These studies focused on reducing the capture of immature individuals of target species. Single-stock assessment methods (Lleonart \& Salat 1997) were then used to investigate the potential effects of improved trawl selectivity on the dynamics of commercial species (Bahamon et al. 2007a,b). However, the overall effects of improved selectivity on commercial species and on other components of the trophic food web in the Mediterranean have remained unclear.

When applying an ecosystem-based approach to the exploitation of marine resources, the effects that fishing is likely to have on ecosystems should be well understood (Browman \& Stergiou 2004). To this end, ecological modeling techniques can be a feasible tool to investigate ecological and management issues. An Ecopath mass-balance model (Christensen \& Walters 2004a) was applied to study the highly exploited South Catalan Sea ecosystem (Coll et al. 2006). This model has recently been calibrated with time series data (Coll et al. 2005, M. Coll et al. unpubl. data).

Due to the availability of a calibrated trophodynamic model and trawl selectivity data, the South Catalan Sea represents an ideal area to evaluate potential consequences of improved trawl selectivity at the ecosystem level, i.e. to assess direct and indirect impacts of fishing conditions and trophic interac- tions. The new European Commission Regulation on the Management of Mediterranean Fisheries (CE 1967/2006) enforces a universal adoption of the $40 \mathrm{~mm}$ SM by July 2008. Therefore, an ecosystem-based assessment of this measure is urgent.

Here we investigated whether an increase in trawl selectivity would have noticeable impacts on the ecosystem in the South Catalan Sea. Using trophodynamic modeling, we ran several simulations with selectivity data as fishing 'experiments'. Predicted biomasses and catches of commercial and non-commercial species were analyzed under various survival scenarios for trawl escapees. In addition, an overall evaluation of general ecosystem changes was performed using ecosystem indicators.

\section{MATERIALS AND METHODS}

Study area. The study area (Fig. 1) on the continental shelf and upper slope associated with the Ebro River Delta, South Catalan Sea (NW Mediterranean) covers soft bottom sediments on a total area of $4500 \mathrm{~km}^{2}$ at depth range between 50 and $400 \mathrm{~m}$ (Díaz et al. 1990). The Catalan Sea is mainly an oligotrophic area where enrichment occurs due to regional wind

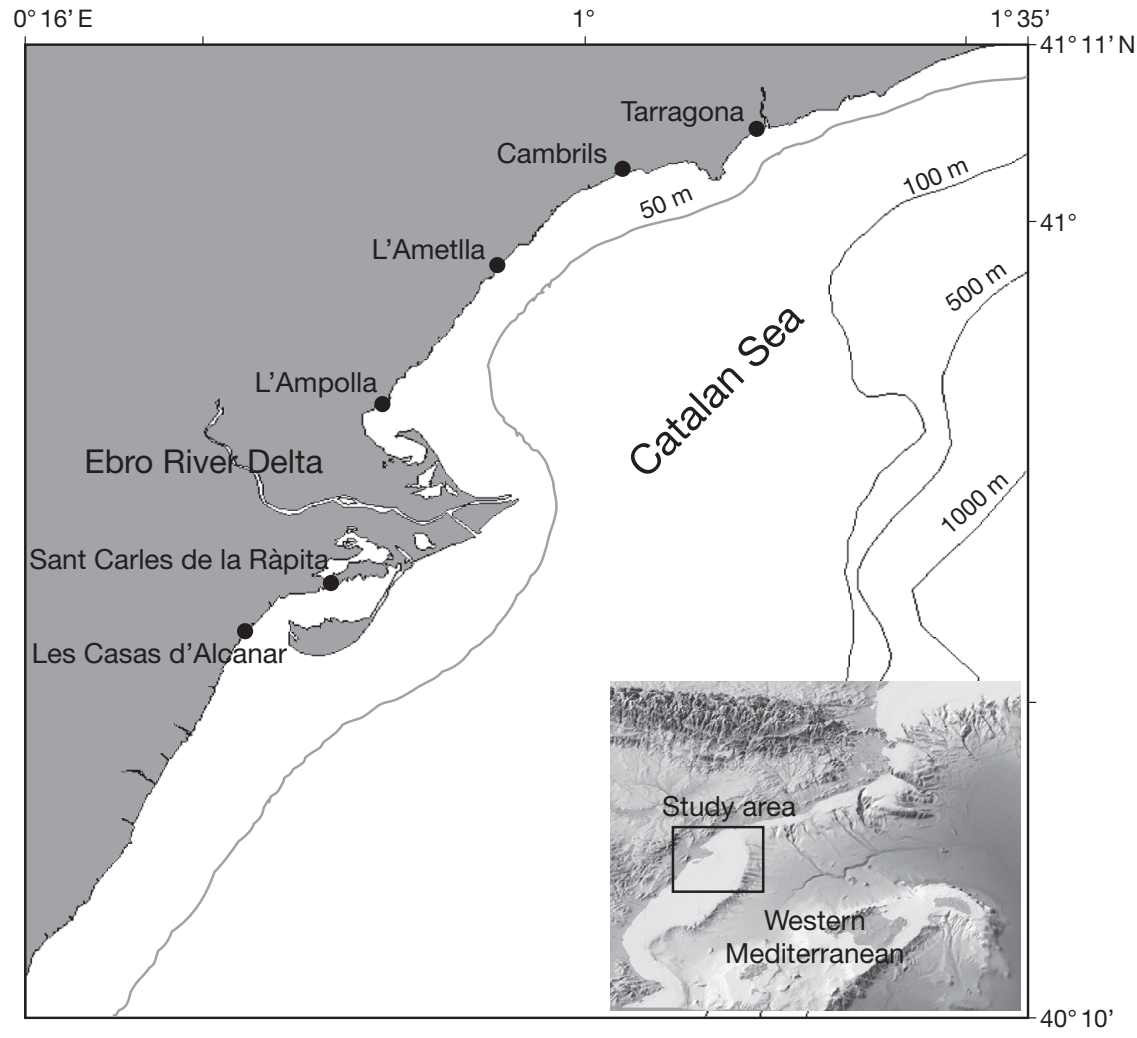

Fig. 1. South Catalan Sea study area (NW Mediterranean) and detail of western Mediterranean basin (inset; modified from Catalano-Balearic Sea-Bathymetric chart 2005, ICM) 
conditions, a seasonal thermocline, a shelf-slope current, and river discharges (Estrada 1996). These natural features have a major influence on primary and secondary productivity, and thereby on the productivity of fishing in the area (e.g. Palomera 1992), which yields almost half of the total fisheries landings of the Catalan coast.

Selectivity data. Selectivity data were obtained from experiments conducted during the summer of 2005 on the commercial fishing grounds at depths between 100 and $400 \mathrm{~m}$ in the South Catalan Sea (Bahamon et al. 2006, 2007a,b). The authors performed a total of 38 tows to assess the selectivity of a commercial $40 \mathrm{~mm}$ DM, as well as an experimental $40 \mathrm{~mm} \mathrm{SM}$ and a sorting grid with $20 \mathrm{~mm}$ bar spacing (SG; Fig. 2). A chartered commercial trawler and the standard covered cod end method (Wileman et al. 1996) were used to assess the selectivity.
In total, 27 commercially exploited species were recorded in the catch. Main target species were hake Merluccius merluccius, blue whiting Micromesistius poutassou, poor cod Trisopterus minutus, greater forkbeard Phycis blennoides, and Norway lobster Nephrops norvegicus. On the continental shelf, hake, gurnard Chelidonichthys gurnardus, spotted flounder Citharus linguatula, and horned octopus Eledone cirrhosa were the most abundant species, representing $54 \%$ of the total catch weight of commercial species. On the upper slope, hake, blue whiting, and greater forkbeard represented $60 \%$ of the total catch weight. Selectivity analyses were performed on those species caught with sufficient frequency and in sufficient numbers, i.e. hake, poor cod, blue whiting, greater forkbeard, and Norway lobster (Bahamon et al. 2006, $2007 \mathrm{a}, \mathrm{b})$. Other species recorded were considered to be accompanying commercial species, i.e. market-

\section{a}

Flexible sorting grid: (20 $\mathrm{mm}$ bar spacing) lowest part opened (20\% of grid area)

\section{Diamond mesh cod end}

$(15 \mathrm{~mm})$

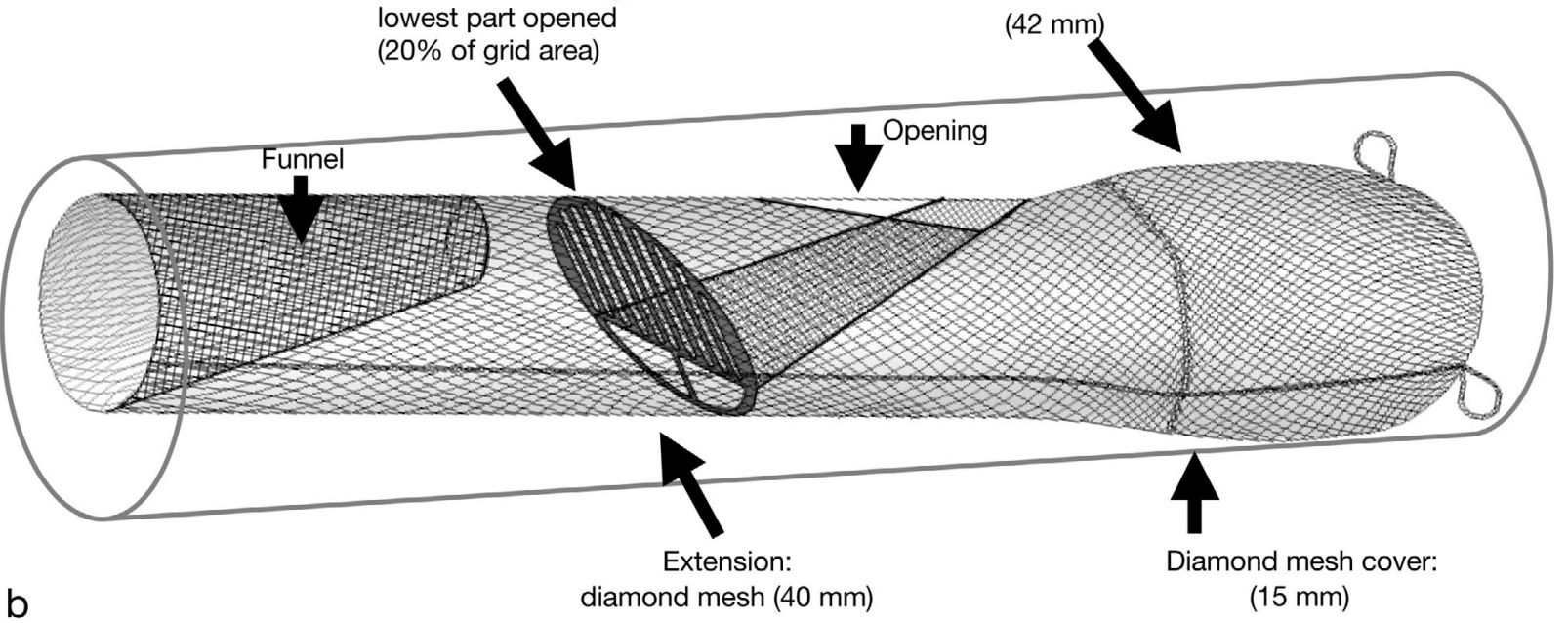

b

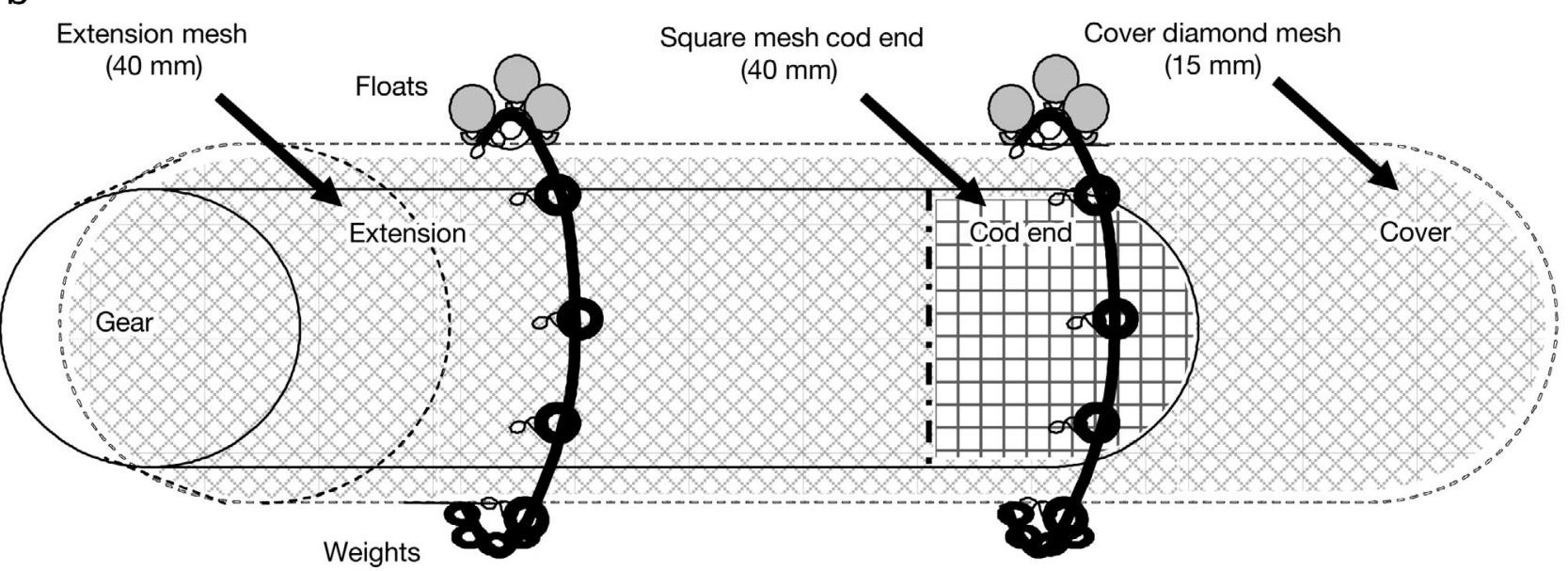

Fig. 2. Schemes of experimental trawling gears. (a) Sorting grid installed in front of the cod end. The upper section of the grid allowed small individuals to escape through the bars out to the cover, while the lower part of the grid guided larger fish into the cod end (current catch). (b) Square mesh cod end. Small fish escaped through the meshes out to the cover, while larger fish remained in the cod end (current catch) 
able by-catch, and were measured in terms of total catch. Selectivity data expressed by length for DM, SM, and SG experiments were re-expressed in terms of total cod end and total cover catches $(\mathrm{kg})$ by tow for commercial species using available lengthweight data (Table 1; Bahamon et al. 2007a,b).

Fishing and post-escape mortality estimates. Using selectivity data, virtual population analysis was performed to calculate mean fishing mortality rates of main target species. Steady state recruitment in the exploited fish stocks and a constant fishing effort was assumed. The analysis used VIT software (Lleonart \& Salat 1997) and growth, lengthweight, and maturity parameters of each species shown in Table 1. Fishing mortality by species associated with DM, SM, and SG scenarios was then calculated for hake, poor cod, blue whiting, greater forkbeard, and Norway lobster (Table 2). The percentage of catch reduction $(\mathrm{kg})$ in the cod end by experiment was also estimated (Table 2).

Data on the mortality by species caused by the escape from trawl gear (post-escape mortality) were extracted from the literature. These data show some similarities between biological groups (crustaceans, demersal fishes, small-sized pelagic fishes; see data in the Appendix). General scenarios of post-escape mortalities by ecological groups were defined (Table 3 ) by considering the general quality (e.g. the number of replicates) of each study in the Appendix. The following general features were identified: (a) fish show higher rates of post-escape mortality than crustaceans; (b) escape mortality decreases with increasing fish length; and (c) pelagic fishes show higher escape mortalities than demersal species.

Trophodynamic modeling. The ecological model from the South Catalan Sea presented by Coll et al. (2006) was used to set the selectivity data presented above within an ecosystem context. The baseline model had been constructed using the Ecopath modeling approach (Christensen \& Walters 2004a) that was used to ensure energy balance:
Table 1 . Von Bertalanffy growth parameters $\left(L_{\infty}, K, t_{\mathrm{o}}\right)$, constants $(a, b)$ for the size-weight relationship and maturity data used in virtual population analysis. Data are mean for males and females

\begin{tabular}{|c|c|c|c|c|c|}
\hline Parameters & $\begin{array}{l}\text { Merluccius } \\
\text { merluccius }^{1}\end{array}$ & $\begin{array}{c}\text { Trisopterus } \\
\text { minutus }\end{array}$ & $\begin{array}{c}\text { Micro- } \\
\text { mesistius } \\
\text { poutassou }^{3}\end{array}$ & $\begin{array}{c}\text { Phycis } \\
\text { blennoides }^{4}\end{array}$ & $\begin{array}{c}\text { Nephrops } \\
\text { norvegicus }^{5}\end{array}$ \\
\hline \multicolumn{6}{|l|}{ Growth } \\
\hline$L_{\infty}(\mathrm{cm})$ & 84.8 & 33.3 & 40.4 & 57.7 & $63.9^{6}$ \\
\hline$K(1 / y r)$ & 0.135 & 0.180 & 0.220 & 0.168 & 0.160 \\
\hline$t_{\mathrm{o}}(\mathrm{yr})$ & -0.364 & -0.910 & -1.290 & -0.660 & -1.395 \\
\hline \multicolumn{6}{|c|}{ L-W relationship } \\
\hline$a$ & 0.0069 & 0.0059 & 0.008 & 0.0012 & 0.0005 \\
\hline$b$ & 3.03 & 3.217 & 2.905 & 3.316 & 3.04 \\
\hline \multicolumn{6}{|l|}{ Maturity } \\
\hline Fertile $\mathrm{L}_{50}(\mathrm{~cm})$ & m) 35.0 & 19.6 & 25.0 & 26.0 & $31.0^{6}$ \\
\hline \multicolumn{6}{|c|}{${ }^{1}$ Catalan Sea (Recasens et al. 1998) } \\
\hline \multicolumn{6}{|c|}{$\begin{array}{l}\text { Eastern Mediterranean (Politou \& Papaconstantinou 1991, Campillo 1992, } \\
\text { Merella et al. 1997) }\end{array}$} \\
\hline \multicolumn{6}{|c|}{${ }^{3}$ Catalan Sea (Calderon-Aguilera 1991, Campillo 1992) } \\
\hline \multicolumn{6}{|c|}{${ }^{4}$ NW Mediterranean (Merella et al. 1997, Froese \& Pauly 2005) } \\
\hline \multicolumn{6}{|c|}{ 5atalan Sea (Sardà et al. 1998). } \\
\hline${ }^{6}$ Units in $\mathrm{mm}$ & & & & & \\
\hline
\end{tabular}

Table 2. Fishing mortalities $\left(\mathrm{yr}^{-1}\right)$ and (parentheses: reduction from initial value, $\%)$, and catch reduction (\%, by weight) in the cod end. Data estimated by species or ecological groups from selectivity experiment in bottom-trawling by shifting from the current $40 \mathrm{~mm}$ diamond mesh cod end (DM40) to $40 \mathrm{~mm}$ square mesh cod end (SM40) or sorting grids with $20 \mathrm{~mm}$ bar spacing (SG20)

\begin{tabular}{|c|c|c|c|c|c|c|}
\hline \multirow[t]{2}{*}{ Species } & \multirow[t]{2}{*}{ Size } & \multicolumn{3}{|c|}{ - Fishing mortality } & \multicolumn{2}{|c|}{ Reduction } \\
\hline & & DM40 & SM40 & SG20 & SM40 & SG20 \\
\hline $\begin{array}{l}\text { Nephrops } \\
\text { norvegicus }\end{array}$ & All & 0.444 & $0.326(-27 \%)$ & $0.302(-32 \%)$ & 5.62 & 7.79 \\
\hline $\begin{array}{l}\text { Trisopterus } \\
\text { minutus }\end{array}$ & All & 1.433 & $0.11(-92 \%)$ & $0.347(-76 \%)$ & 32.71 & 20.37 \\
\hline $\begin{array}{c}\text { Micromesistius } \\
\text { poutassou }\end{array}$ & s All & 0.415 & $0.337(-19 \%)$ & $0.222(-47 \%)$ & 27.53 & 55.09 \\
\hline $\begin{array}{l}\text { Phycis } \\
\text { blennoides }\end{array}$ & All & 0.237 & $0.138(-42 \%)$ & $0.11(-54 \%)$ & 46.86 & 17.47 \\
\hline $\begin{array}{l}\text { Merluccius } \\
\text { merluccius }\end{array}$ & $\begin{array}{l}\leq 25 \mathrm{~cm} \\
>25 \mathrm{~cm}\end{array}$ & $\begin{array}{l}0.769 \\
0.376\end{array}$ & $\begin{array}{l}0.519(-33 \%) \\
0.423(+13 \%)\end{array}$ & $\begin{array}{l}0.556(-28 \%) \\
0.214(-43 \%)\end{array}$ & $\begin{array}{c}35.57 \\
0.00\end{array}$ & $\begin{array}{c}29.05 \\
0.00\end{array}$ \\
\hline Other species & All & 0.612 & $0.309(-42 \%)$ & $0.292(-47 \%)$ & 24.72 & 21.63 \\
\hline
\end{tabular}

Table 3. Post-escape mortality ( $\%$ increase) by species group (revision of data presented in Appendix 1)

\begin{tabular}{|lc|}
\hline Groups of species & Mortality (\%) \\
\hline Shrimps, crabs, and cephalopods & 15 \\
Benthic invertebrates & 50 \\
Flatfish & 30 \\
Small demersal fishes & 75 \\
Medium-sized demersal fishes & 40 \\
Small and medium-sized pelagic fishes & 90 \\
\hline
\end{tabular}




$$
P_{i}=\sum_{j} B_{i} \times M 2_{i j}+Y_{i}+E_{i}+B A_{i}+P_{i} \times\left(1-E E_{i}\right)
$$

where production $(P)$ of each component or functional group (i) of the ecosystem equals predation mortality $\left(M 2_{i j}\right)$ caused by the biomass $\left(B_{j}\right)$ of the other predators $(j)$, exports from the system both in terms of fishing catch $\left(Y_{i}\right)$ and emigration $\left(E_{i}\right)$, biomass accumulation in the ecosystem $\left(B A_{i}\right)$, and baseline mortality or other mortality $\left(1-E E_{i}\right)$. $E E$ is the ecotrophic efficiency of the group within the system, or the proportion of the production of (i) that is exported out of the ecosystem (i.e. by fishing activity) or consumed by predators within it. The energy balance within each group is ensured when consumption by group (i) equals production by (i), respiration by (i), and food that is unassimilated by (i).

The model represented an average annual situation (in 1994) of the ecosystem on continental shelf and upper slope areas influenced by the Ebro River delta. It included 40 functional groups (Fig. 3) spanning the main trophic components of the ecosystem from low to high TLs, considering target and non-target vertebrate and invertebrate groups, detritus groups, and 4 fishing fleets: bottom-trawling, purse-seining, long-lining, and bait-trolling (or large pelagic fish fleets). The model also took into account migratory patterns of Atlantic bonito Sarda sarda, large pelagic fishes (Atlantic bluefin tuna Thunnus thynnus and swordfish Xiphias gladius), fin whale Balaenoptera physalus, and marine turtles (Caretta caretta; Coll et al. 2006), through diet imports and biomass flux. Poor cod, blue whiting, and Norway lobster corresponded to single functional groups of the model, while greater forkbeard was included within 'Demersal fish mixed-group (1)' (a mixed group of demersal fish species feeding on small demersal fish and crustaceans). Hake was divided in 2 functional groups, juveniles and adults, due to data availability.

Time series from 1978 to 2003 of fishing effort by fleet and catches by species, from governmental statistics, and biomasses of some commercial demersal and pelagic fishes and seabirds, from oceanographic and

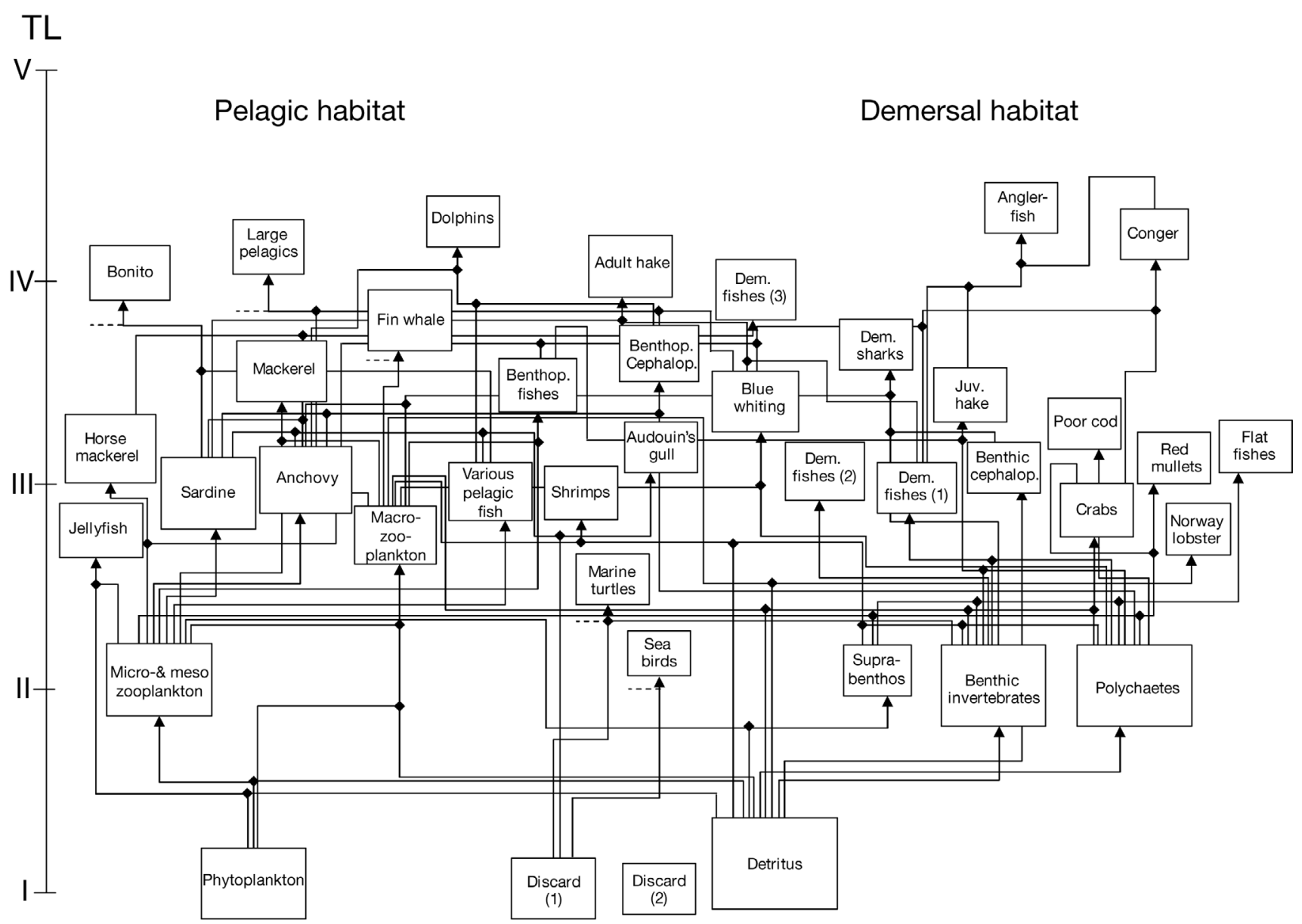

Fig. 3. Flow diagram of South Catalan Sea model organized by functional groups and fractionated trophic levels (TL) and divided between demersal and pelagic habitats. Dem.: demersal; Benthop.: benthopelagic; Cephalop: cephalopod; Juv.: juvenile. Dashed lines indicate that a fraction of the trophic flows are exported out of the system 
fishing surveys, were used to calibrate the model (Coll et al. 2005 and unpubl. data) applying the temporal dynamic module Ecosim (Christensen \& Walters 2004a).

Ecosim describes a system of differential equations from the baseline mass-balance model (Eq. 1) where the growth rate during time of each functional group (i) in terms of its biomass $\left(\delta B_{i} / \delta t\right)$ is:

$$
\frac{\delta B_{i}}{\delta_{i}}=\left(\frac{P}{Q}\right)_{i} \times \sum Q_{j i}-\sum Q_{j i}+I_{i}-\left(M_{i}+F_{i}+e_{i}\right) \times B_{i}
$$

culated from the reduction of initial to final fishing mortality, considering selectivity improvement and post escape mortality (Tables $2 \& 3$ ). Initially, simulations were run for $5 \mathrm{yr}$ without a change in fishing mortalities so that stability was reached prior to perturbation of the ecosystem, and then runs continued for an additional $20 \mathrm{yr}$ (when equilibrium was reached) considering the experimental selectivity data. Vulnerability settings from the calibrated model were included where $(P / Q)_{i}$ is the gross efficiency calculated from the production $(P)$ and consumption $(Q)$ ratio; $M_{i}$ is the nonpredation natural mortality rate; $F_{i}$ is the fishing mortality rate; $e_{i}$ is the emigration rate; $I_{i}$ is the immigration rate; and $e_{i} \times B_{i}-I_{i}$ is the net migration rate. Calculations of $Q$ by functional group are based upon the 'foraging arena' theory, where the biomass of (i) is divided between a vulnerable and nonvulnerable fraction and the transfer rate between the 2 fractions determines the flow control (bottom-up, top-down, or mixed). Vulnerabilities by functional group and an environmental anomaly function linked to phytoplankton production to take into account environmental variability were calculated as a result of the fitting process (Coll et al. 2005 and unpubl. data). A critical review of Ecopath with the Ecosim approach can be found in Christensen \& Walters (2004a) and Fulton \& Smith (2004).

Selectivity simulations and analysis of results. Ecosim and the trophodynamic model representing the South Catalan Sea using a time series of biological data, vulnerability settings, environmental forcing functions, and changes in fishing pressure from 1978 to 2003 (explained above) was used to derive a new model representing the ecosystem in 2003 (Table 4). This model output was then used as the initial conditions for performing temporal simulations of expected scenarios after improving bottom trawl selectivity. The model was forced by changing fishing mortality $\left(F_{i}\right)$ in Eq. 2 and using a csv driver file (a comma-separated list or comma-separated variables file that stores tabular data). The new fishing mortality by functional group was cal-
Table 4. Input $(B, P / B, Q / B)$ and output data $(T L, E E)$ of the South Catalan Sea ecosystem model (2003) by functional group. $B$ : initial biomass $\left(\mathrm{t} \mathrm{km}^{-2}\right) ; P / B$ : production/biomass ratio $\left(\mathrm{yr}^{-1}\right) ; Q / B$ : consumption/biomass ratio $\left(\mathrm{yr}^{-1}\right)$; Catch: landings and discards $\left(\mathrm{t} \mathrm{km}^{-2} \mathrm{yr}^{-1}\right)$; TL: trophic level; EE: ecotrophic efficiency; F/Z: exploitation rate

\begin{tabular}{|c|c|c|c|c|c|c|c|}
\hline $\begin{array}{l}\text { Functional } \\
\text { group }\end{array}$ & $B$ & $P / B$ & $Q / B$ & Catch & $\mathrm{TL}$ & $E E$ & $F / Z$ \\
\hline 1 Phytoplankton & 9.70 & 162.22 & & - & 1.0 & 0.13 & - \\
\hline $\begin{array}{l}2 \text { Micro and } \\
\text { mesozooplankton }\end{array}$ & 6.02 & 20.96 & 49.13 & - & 2.05 & 0.84 & - \\
\hline 3 Macrozooplankton & 0.44 & 20.41 & 50.98 & - & 2.77 & 0.82 & - \\
\hline 4 Jellyfish & 0.32 & 13.82 & 50.31 & - & 2.83 & 0.22 & - \\
\hline 5 Suprabenthos & 0.08 & 7.95 & 51.10 & - & 2.10 & 0.92 & - \\
\hline 6 Polychaetes & 12.42 & 1.74 & 11.47 & - & 2.00 & 0.31 & - \\
\hline 7 Shrimps & 0.06 & 2.85 & 6.96 & 0.004 & 3.00 & 0.98 & 0.02 \\
\hline 8 Crabs & 0.16 & 2.11 & 4.87 & 0.131 & 2.89 & 0.98 & 0.38 \\
\hline 9 Norway lobster & 0.01 & 1.29 & 5.14 & 0.005 & 2.83 & 0.96 & 0.37 \\
\hline $\begin{array}{l}10 \text { Benthic } \\
\text { invertebrates }\end{array}$ & 11.73 & 1.05 & 3.14 & 0.001 & 2.04 & 0.45 & 0.0001 \\
\hline $\begin{array}{l}11 \text { Benthic } \\
\text { cephalopods }\end{array}$ & 0.26 & 2.58 & 5.68 & 0.467 & 3.09 & 0.98 & 0.69 \\
\hline $\begin{array}{l}12 \text { Benthopelagic } \\
\text { cephalopods }\end{array}$ & 0.09 & 2.22 & 29.98 & 0.058 & 3.66 & 0.91 & 0.28 \\
\hline 13 Mullets & 0.22 & 2.21 & 7.09 & 0.020 & 3.19 & 0.07 & 0.04 \\
\hline 14 Conger eel & 0.01 & 1.97 & 5.00 & 0.017 & 4.35 & 0.99 & 0.84 \\
\hline 15 Anglerfish & 0.01 & 1.69 & 4.11 & 0.019 & 4.40 & 1.00 & 0.86 \\
\hline 16 Flatfishes & 0.01 & 3.17 & 11.41 & 0.026 & 3.25 & 0.98 & 0.84 \\
\hline 17 Poor cod & 0.01 & 1.80 & 7.97 & 0.018 & 3.48 & 0.95 & 0.72 \\
\hline 18 Juvenile hake & 0.04 & 1.30 & 7.37 & 0.008 & 3.69 & 0.35 & 0.16 \\
\hline 19 Adult hake & 0.34 & 0.60 & 2.52 & 0.018 & 4.15 & 0.47 & 0.60 \\
\hline 20 Blue whiting & 0.73 & 0.57 & 6.15 & 0.087 & 3.37 & 0.71 & 0.21 \\
\hline 21 Demersal fish (1) & 0.37 & 1.38 & 8.19 & 0.342 & 3.10 & 0.99 & 0.66 \\
\hline 22 Demersal fish (2) & 0.06 & 1.02 & 6.69 & 0.024 & 3.03 & 0.74 & 0.37 \\
\hline 23 Demersal fish (3) & 0.16 & 0.60 & 5.82 & 0.044 & 3.89 & 0.99 & 0.46 \\
\hline $\begin{array}{l}24 \text { Demersal small } \\
\text { sharks }\end{array}$ & 0.002 & 0.72 & 6.88 & 0.002 & 3.76 & 0.97 & 0.88 \\
\hline 25 Bentopelagic fish & 0.54 & 1.37 & 8.21 & 0.148 & 3.46 & 0.92 & 0.20 \\
\hline 26 European anchovy & 2.19 & 1.11 & 13.31 & 0.777 & 3.05 & 0.73 & 0.32 \\
\hline 27 European pilchard & 3.28 & 1.50 & 8.69 & 2.620 & 2.97 & 1.00 & 0.53 \\
\hline 28 Small pelagic fish & 0.60 & 0.47 & 7.71 & 0.081 & 3.00 & 1.00 & 0.29 \\
\hline 29 Horse mackerel & 0.85 & 0.36 & 5.35 & 0.086 & 3.17 & 0.57 & 0.28 \\
\hline 30 Mackerel & 0.22 & 0.37 & 5.23 & 0.005 & 3.55 & 0.55 & 0.06 \\
\hline 31 Atlantic bonito & 0.26 & 0.67 & 4.15 & 0.032 & 4.02 & 0.18 & 0.18 \\
\hline 32 Large pelagic fish & 0.10 & 0.53 & 1.65 & 0.015 & 4.21 & 0.29 & 0.29 \\
\hline 33 Loggerhead turtles & 0.03 & 0.18 & 2.59 & 0.0003 & 2.56 & 0.06 & 0.06 \\
\hline 34 Audouin's gull & 0.0005 & 4.72 & 71.77 & 0.00002 & 2.77 & - & - \\
\hline 35 Other sea birds & 0.0003 & 6.82 & 109.94 & 0.00002 & 2.05 & 0.13 & 0.01 \\
\hline 36 Dolphins & 0.001 & 0.08 & 13.49 & 0.00002 & 4.36 & 0.22 & 0.22 \\
\hline 37 Fin whale & 0.23 & 0.04 & 4.09 & - & 3.80 & 0.00 & - \\
\hline 38 Discards & 0.54 & - & - & - & 1.0 & 0.61 & - \\
\hline 39 By-catch & 0.002 & - & - & - & 1.0 & 0.00 & - \\
\hline 40 Detritus & 69.60 & - & - & - & 1.0 & 0.17 & - \\
\hline
\end{tabular}


to perform dynamic simulations, whereas the remaining ecological parameters and the environmental anomaly function were maintained by default from the initial model.

The decrease in total fishing mortality $\left(F_{t}\right)$ by functional group (i) with the SM or SG compared to that of DM (current situation) was a new input of the model and was calculated according to a decrease in fishing mortality (Table 2) based on Eq. $2\left(F_{i}\right)$ :

$$
F_{t, i}=F_{\text {pseine }_{i}}+F_{\text {longline }_{i}}+F_{\text {bait }_{i}}+F_{\text {trawl }_{s, i}}
$$

where $F_{\text {pseine }_{i}}$ is the fishing mortality due to purse-seining, $F_{\text {longline }_{i}}$ is due to long-lining, $F_{\text {bait }_{i}}$ is due to baittrolling, and $F_{\text {trawl }_{s, i}}$ is due to bottom-trawling after selectivity measures are applied. The potential increase in fishing-induced mortality due to escape (Table 3) was also taken into account as follows:

$$
\begin{gathered}
F_{t, i}=F_{\text {pseine }_{i}}+F_{\text {longline }_{i}}+F_{\text {bait }_{i}}+ \\
\left(F_{\text {trawl }_{s, i}}+F_{\text {trawl }_{e} i}\right)
\end{gathered}
$$

where $F_{\text {trawl }}, i$ is the increase in fishing mortality due to escape.

Three scenarios were simulated from 2003 (Table 5), after the hypothetical introduction of the selectivity

Table 5. Dynamic simulations performed to assess selectivity enhancement (2003 to 2030) by including square mesh (SM) and sorting grid (SG) selectivity data in the ecosystem model of the South Catalan Sea and shown in Fig. 4 to Fig. 9 and in Table 6

\begin{tabular}{|cl|}
\hline $\begin{array}{c}\text { Dynamic } \\
\text { simulations }\end{array}$ & Description \\
\hline $\begin{array}{c}\text { Scenario 1 } \\
\text { SM_1 }\end{array}$ & $\begin{array}{l}\text { Square mesh considering commercial } \\
\text { species (Table 2) }\end{array}$ \\
SG_1 & $\begin{array}{l}\text { Sorting grid considering commercial } \\
\text { species (Table 2) }\end{array}$ \\
Scenario 2 & $\begin{array}{l}\text { Square mesh considering commercial } \\
\text { an_2 }\end{array}$ \\
post-escape mortality (Table 3) \\
SG_2 & $\begin{array}{l}\text { Sorting grid considering commercial } \\
\text { and accompanying species including } \\
\text { post-escape mortality (Table 3) }\end{array}$ \\
Scenario 3 & $\begin{array}{l}\text { Square mesh considering commercial } \\
\text { Species including a global estimate for } \\
\text { the remaining accompanying species } \\
\text { (Table 2) } \\
\text { Sorting grid considering commercial } \\
\text { species including a global estimate for } \\
\text { the remaining accompanying species } \\
\text { (Table 2) }\end{array}$ \\
SG_3 & \\
&
\end{tabular}

devices, considering selectivity data from: (Scenario 1) commercial species only (using square mesh, SM_1, and sorting grids, SG_1); (Scenario 2) commercial species and a mean estimate for remaining accompanying species, i.e. marketable by-catch and noncommercial species (using square mesh, SM_2, and sorting grids, SG_2); and (Scenario 3) commercial, accompanying. and non-commercial species, and the post-escape mortality (using square mesh, SM_3, and sorting grids, SG_3).

The output of simulations was analyzed in terms of biomass ratios before (i) and after ( $f$ ) selectivity $(B f / B i)$ by target and non-target demersal species or functional groups (2003-2030), total biomass (B) and catch $(C)$ ratios $(B f / B i$ and $C f / C i)$, and catch by fleet (t $\mathrm{km}^{-2}$ ). Biomass ratios of small and large-sized pelagic fish, jellyfish, and benthopelagic fish were also included to analyze the potential effects on the pelagic compartment.

The overall ecosystem effects of selectivity measures were assessed by calculating: (1) total ecosystem biomass $\left(B_{t} / B_{0}\right)$, (2) total fishable biomass $\left(B f_{t} / B f_{0}\right)$, (3) total top predator biomass $\left(B p_{f} / B p_{0}\right)$ (including adult hake, anglerfish, demersal sharks, Atlantic bonito, Atlantic bluefin tuna, and swordfish), (4) mean trophic level of the community $\left(\mathrm{TL}_{\mathrm{CO}}\right),(5)$ mean trophic level of the catch $\left(\mathrm{TL}_{\mathrm{C}}\right),(6)$ total catches $\left(C_{\mathrm{t}}\right)$, and (7) a modified version of Kempton's index of biodiversity (Pauly et al. 1998, Christensen \& Walters 2004b). Both TLco and TLc indicators are expected to decrease when fishing impact increases, because large predators are being reduced in ecosystems while lower TL organisms prevail (Pauly et al. 1998, Jennings et al. 2002). The modified version of Kempton's index of biodiversity, or Biomass Diversity Index $\left(Q^{\prime}\right)$, is a relative index of biomass diversity calculated from Kempton's $Q_{75}$ index developed for expressing species diversity (Kempton \& Taylor 1976, Christensen \& Walters 2004b). This index includes those species or functional groups with a TL of 3 or higher, so an increase on this index implies the increase in biomass of various high TL organisms.

Because the data were not normally distributed and were non-linear, the significance of Ecosim results in terms of biomass simulations was measured by applying the Spearman non-parametric correlation coefficient. Ecosim was used to test sensitivity of temporal simulation outputs to initial parameters of the baseline model by applying a Monte Carlo routine (Christensen \& Walters 2004a, Christensen et al. 2005). To provide defaults for the Ecoranger routine of Ecopath, and thus allow explicit consideration of uncertainties in the inputs, model pedigree values (Coll et al. 2006) were used. Coefficients of variation (CV) set by default were: sampling-basedhigh-precision $(\mathrm{CV}=10 \%)$, sampling-based-lowprecision $(\mathrm{CV}=30 \%)$; indirect method $(\mathrm{CV}=50 \%)$, and 
other method $(\mathrm{CV}=80 \%)$. Monte Carlo simulations were run with initial Ecopath estimates $(B, P / B, Q / B$, and DC: Christensen \& Walters [2004a]) chosen from normal distributions centered on the initial inputs of the model. Each simulation begins by selecting random input combinations from the baseline model unless it is not balanced. The model results were used to develop dynamic simulations, and the mean and the SD of 20 runs by simulation were calculated.

\section{RESULTS}

\section{Changes in biomasses}

Biomass ratios (Bf/Bi) of commercial species (Fig. 4) - when assuming that the whole trawler fleet used a $40 \mathrm{~mm}$ SM or a sorting grid with a $20 \mathrm{~mm}$ bar-spacing (SG) - showed marked differences when considering commercial species alone (Scenario 1, SM_1 and SG_1), commercial and accompanying species (Scenario 2, SM_2 and SG_2), and adding the post-escape mortality (Scenario 3, SM_3 and SG_3; Table 5). In
Scenarios 1 and 2, substantial increases and decreases in biomass of species were observed, while in Scenario 3 , changes were minor. Scenario 3 showed that an increase in trawl selectivity would cause a significant decrease in the biomass of Norway lobster (8 to 10\% from initial biomass when implementing both selectivity devices), blue whiting (both $3 \%$ ), and juvenile hake (11 to $13 \%$ ), while there was a significant increase for the demersal fish mixed group (37 to $47 \%$ ) and adult hake $(6$ to $8 \%$; levels of significance are given in Table 6).

Impacts on the biomass of other functional groups were also predicted. Top predators of the ecosystem (with TL from 3 to 5) apart from adult hake, such as anglerfish, demersal sharks, Atlantic bonito, and large pelagic fishes (Fig. 4) showed greater changes in biomass when taking into account data from noncommercial species and post-escape mortality (i.e. Scenarios 2 and 3). This increase was significant for anglerfish in all scenarios (Table 6).

In terms of low-TL organisms (TL from 2 to 3), remarkable changes (mainly decreases) in the biomass of suprabenthos, crabs, shrimps, and benthic cephalo-
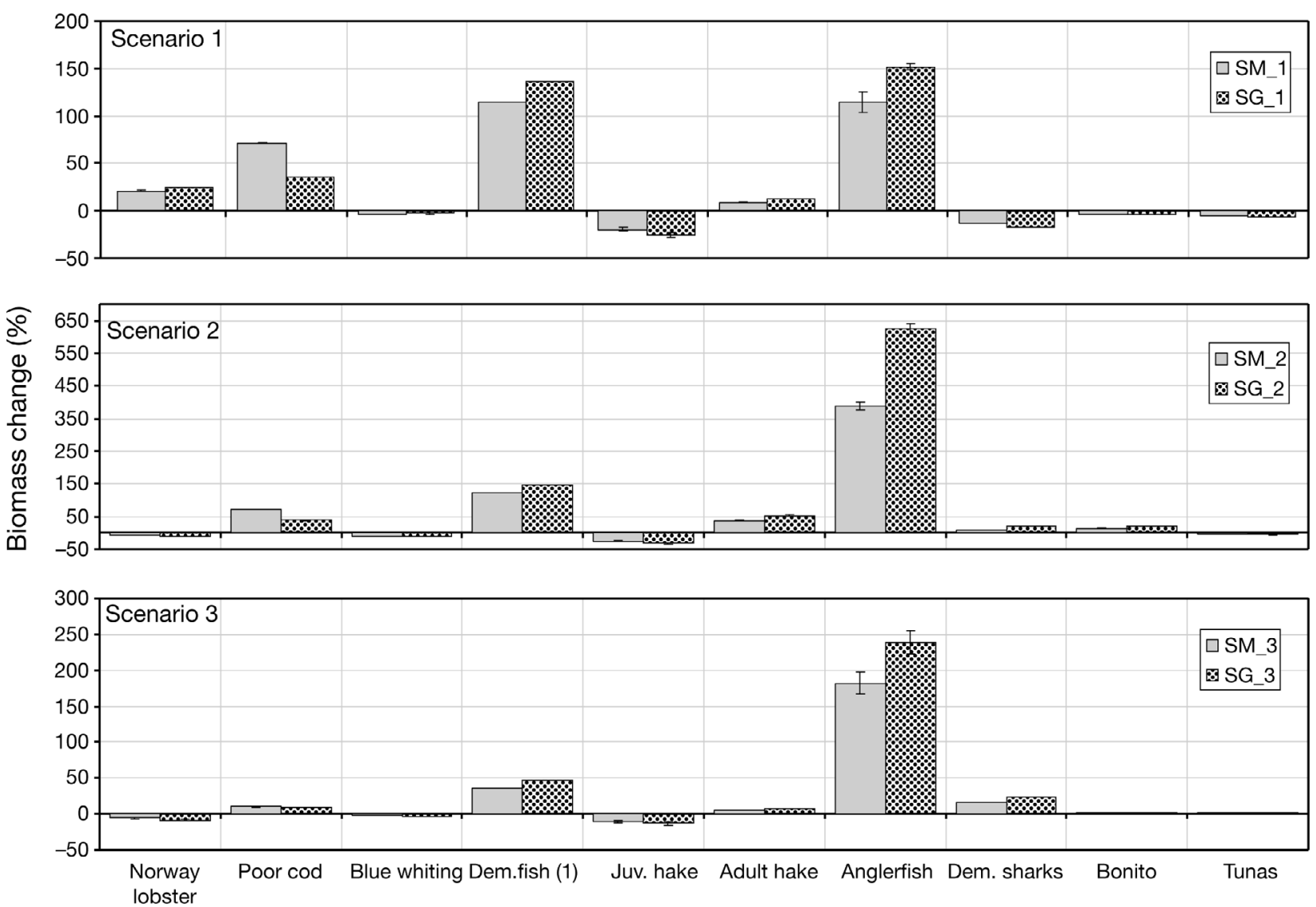

Fig. 4. Biomass change (\%) of commercial species and top predators calculated from temporal dynamic simulation by including square mesh (SM) and sorting grid (SG) selectivity data in the ecosystem model of the South Catalan Sea (2003 to 2030; simulations are described in Table 5). Error bars: SD. Dem.: demersal; Juv.: juvenile 


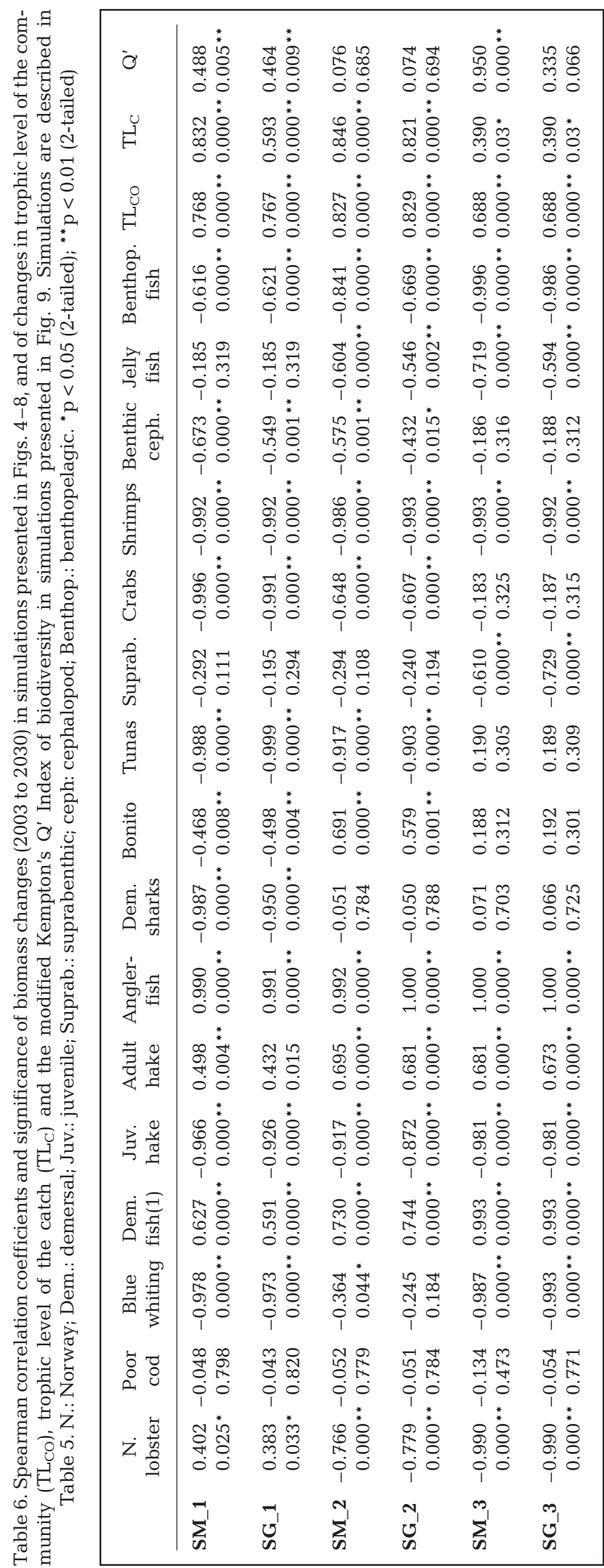

pods due to the increase of trawl selectivity were also observed (Fig. 5). This decrease was significant for suprabenthos (both 5\%) and shrimps (26 to $31 \%$ ) in Scenario 3 (Table 6).

Total biomass of demersal invertebrates decreased in all scenarios ( 2 to $0.2 \%$ ), while the biomass of demersal fishes increased ( 7 to $33 \%$; Fig. 6). Biomass of small and medium-sized pelagic fish showed a slight increase when considering commercial species and the rest of the accompanying species (Scenario 2, 4 to $6 \%$ ) or when adding post-escape mortality (Scenario 3, 0.3 to $0.5 \%$ ).

\section{Changes in catch}

A decrease in catches of Norway lobster, poor cod, blue whiting, and juvenile hake were predicted under all scenarios (Fig. 7). However, decreases in catches for poor cod (11 to $16 \%$ ), blue whiting ( 7 to $14 \%$ ), and juvenile hake (15 to $16 \%$ ) were smaller in Scenario 3. In contrast, catches of the demersal fish mixed group (1) and adult hake increased, although the uncertainty for adult hake was higher. Generally, total catches of these commercial groups increased in all scenarios (14 to $28 \%$ ).

Simulations predicted catch declines for trawling and purse-seining fleets (Fig. 8), although the decrease was lower in the third scenario ( 4 to $6 \%$ and 0.3 to $0.4 \%$ for trawling and purse-seining, respectively). In contrast, an increase in catch was predicted in long-line fishery ( 2 to $13 \%$ ), although the error was high, and in baittrolling for Scenario 3 (1 to $2 \%$ ). The overall simulations predicted a decrease in catches from 2 to $5 \%$.

\section{Ecosystem indicators}

Total ecosystem biomass $\left(B_{t} / B_{0}\right)$ and fishable biomass $\left(B f_{t} / B f_{0}\right.$; Fig. 6) indicated small changes in all scenarios, but especially in Scenario 3 (0.2 to $0.4 \%$ ). Top predator biomass $\left(B p_{f} / B p_{0}\right)$ showed a marked increase, which was lower in Scenario 3 (5 to $7 \%$ ).

Biomass predictions of jellyfish and benthopelagic fish species showed a decrease in all scenarios (2 to $16 \%$ for jellyfish and 4 to $21 \%$ for benthopelagic species; Fig. 5), and the decrease was significant for both groups in Scenarios 2 and 3 (Table 6).

A significant increase in the mean $\mathrm{TL}_{\text {co }}(0.2$ to $0.8 \%)$ and the mean $\mathrm{TL}_{\mathrm{c}}(0.1$ to $0.3 \%$ ) was predicted (Fig. 9, Table 6), although the latter showed higher uncertainty. The modified Kempton's Q' of biodiversity also increased in all cases (16 to $30 \%$ ), and was significant in Scenario 1 and in Scenario 3 when using square mesh (Table 6). 

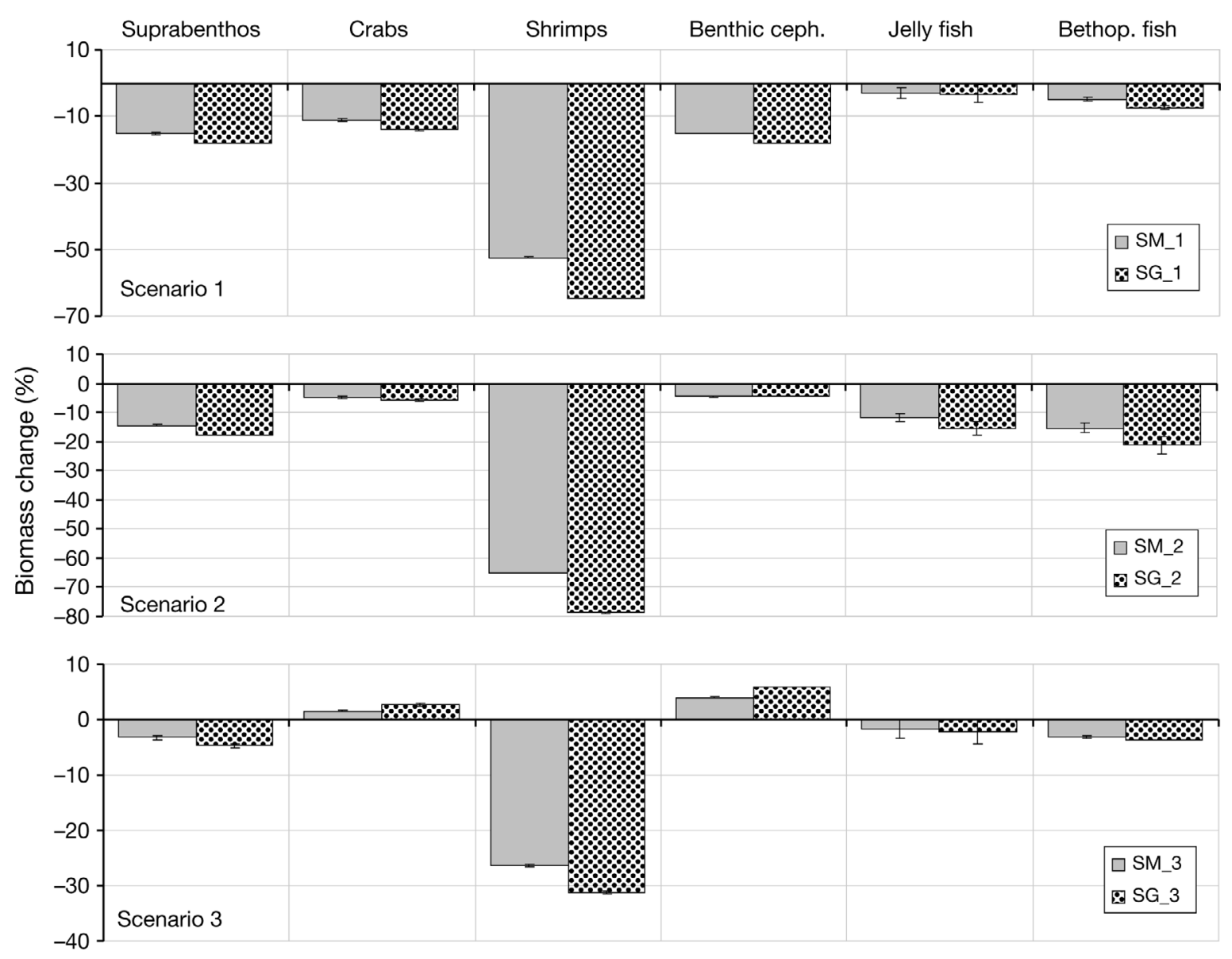

Fig. 5. Biomass change (\%) of low trophic level species or groups calculated from temporal dynamic simulation by including square mesh (SM) and sorting grid (SG) selectivity data in the ecosystem model of the South Catalan Sea (2003 to 2030; simulations are described in Table 5). Error bars: SD. Ceph.: cephalopods; Benthop.: benthopelagic
a) Total
b) Fishable
c) Top predators
d) Pelagic fish
e) Demersal fish
f) Demersal invertebrates

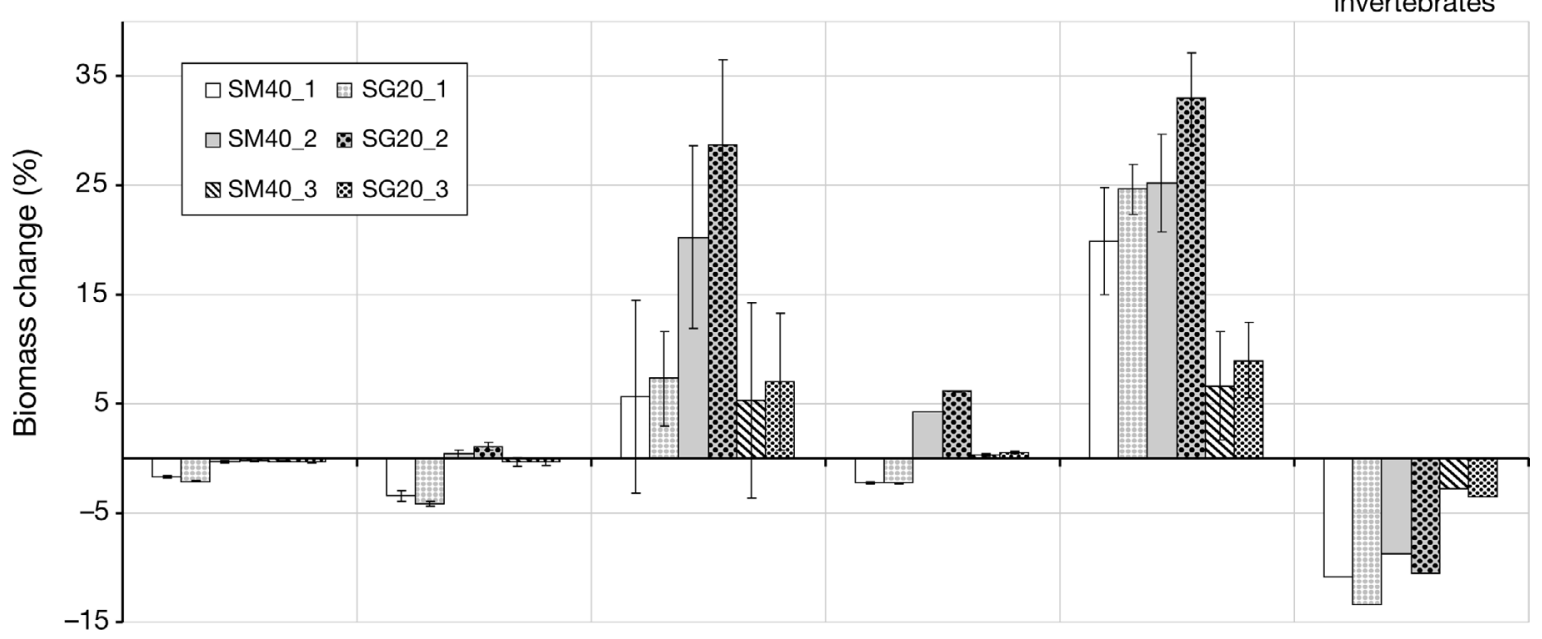

Fig. 6. Biomass change (\%) calculated from temporal dynamic simulation by including square mesh (SM) and sorting grid (SG) selectivity data in the ecosystem model of the South Catalan Sea (2003 to 2030) for (a) all functional groups in the model, (b) fishable groups, (c) top predators, (d) small and medium-sized pelagic fish species, (e) demersal fish species, and (f) demersal invertebrates (simulations are described in Table 5). Error bars: SD 


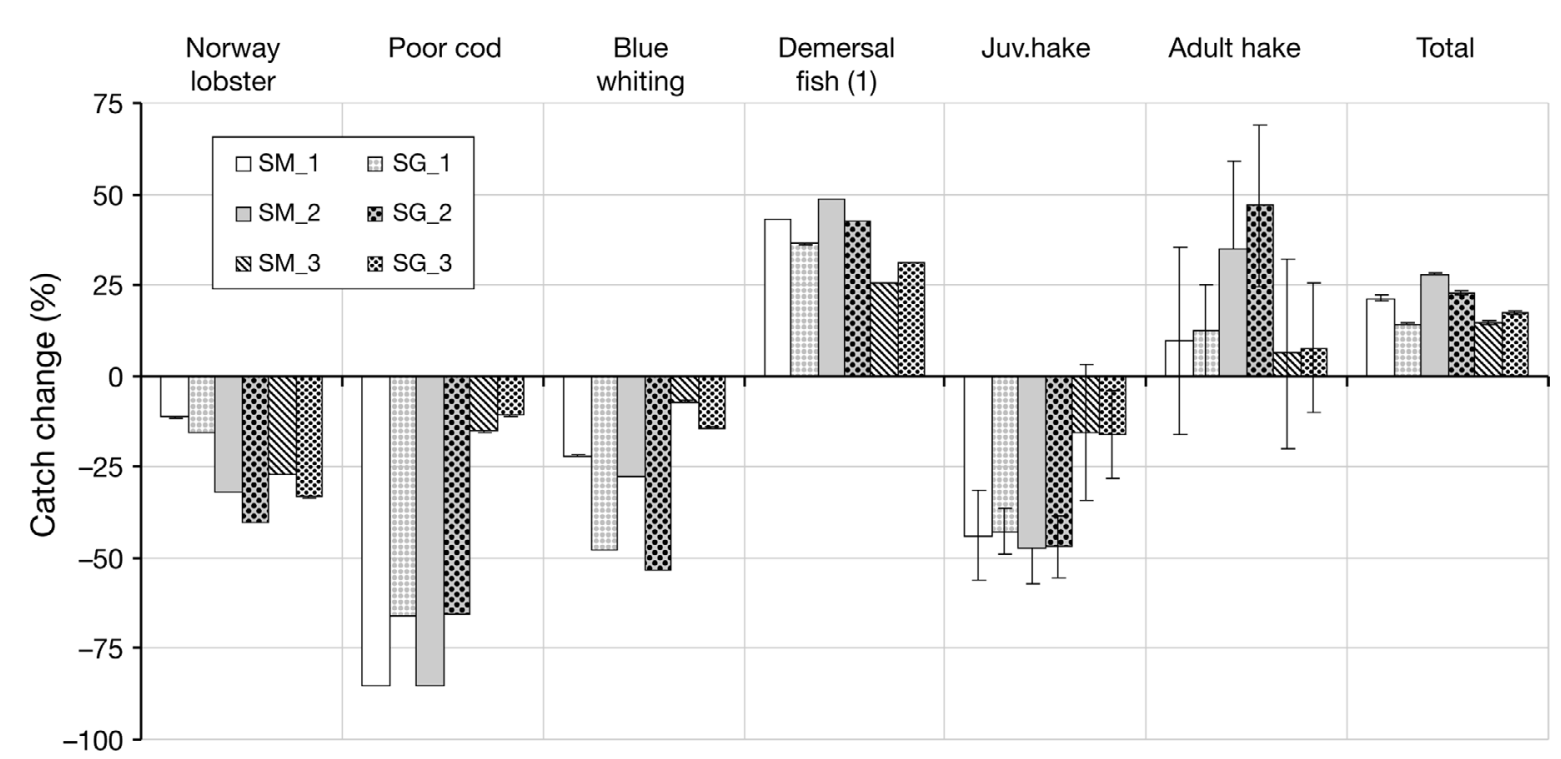

Fig. 7. Catch change (\%) resulting from temporal dynamic simulation by including square mesh (SM) and sorting grid (SG) selectivity data in the ecosystem model of the South Catalan Sea (2003 to 2030) for several commercial species (simulations are described in Table 5). Error bars: SD. Juv.: Juvenile

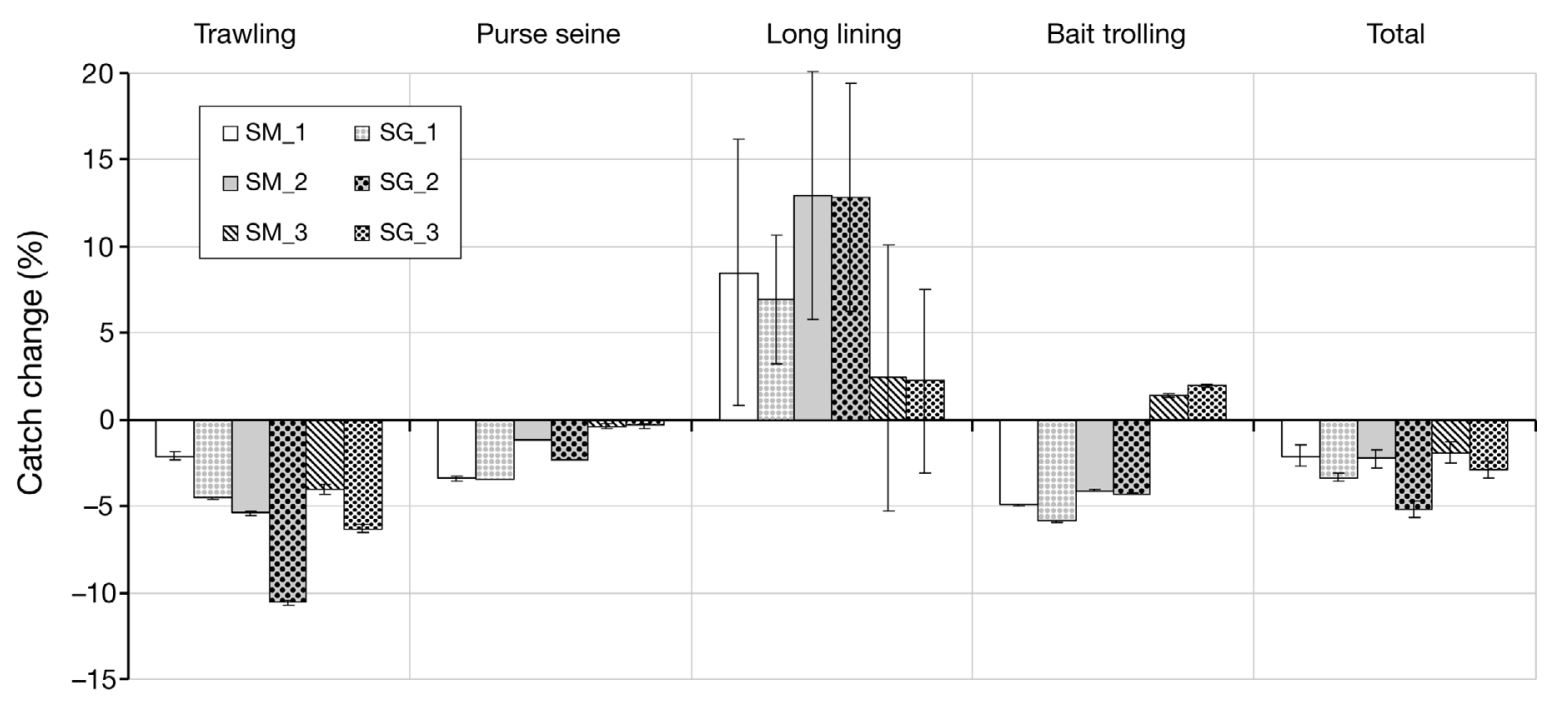

Fig. 8. Catch change (\%) resulting from temporal dynamic simulation by including square mesh (SM) and sorting grid (SG) selectivity data in the ecosystem model of the South Catalan Sea (2003 to 2030) for various fishing fleets and total catches (simulations are described in Table 5). Error bars: SD

\section{DISCUSSION}

Our study discloses potentially significant impacts on biomass of different species and ecological groups as a consequence of an increase in bottom trawl selectivity in a highly multispecies fishery. Results highlight the importance of accounting not only for commercial but also for non-commercial species and the post-escape mortality when evaluating the effects of selectivity measures. Fishing takes place within an ecosystem where target and non-target species have complex interactions, and changes in species dynamics are subjected to changes in predation mortality, competition, and trophic cascades (Cury et al. 2003). Our study demonstrates that ecosystem impacts of improved trawl selectivity in the South Catalan Sea are complex.

Both selectivity devices examined, namely the $40 \mathrm{~mm}$ SM and sorting the grid with $20 \mathrm{~mm}$ bar- 

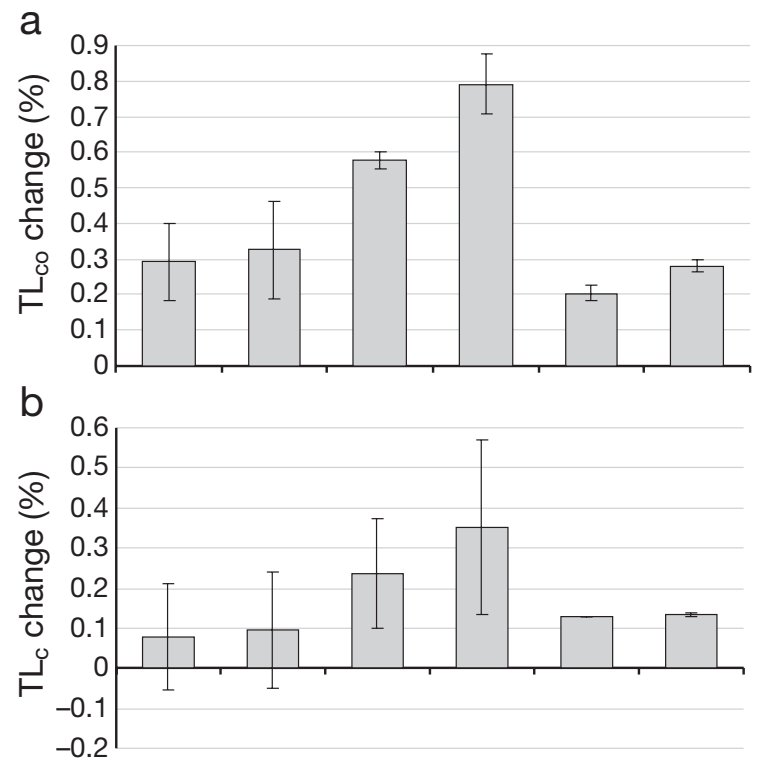

C

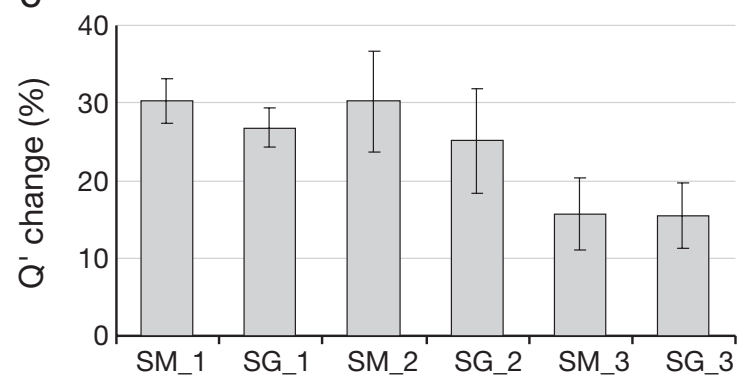

Fig. 9. Changes (\%) in (a) mean trophic level of community, (b) mean trophic level of catch, and (c) modified Kempton's $\mathrm{Q}^{\prime}$ resulting from temporal dynamic simulation (2003 to 2030) by including square mesh (SM) and sorting grid (SG) selectivity data in the ecosystem model of the South Catalan Sea

(simulations are described in Table 5). Error bars: SD

spacing, perform similarly in terms of biomass and catch. However, the implementation of a sorting grid would offer greater advantages to top predators of the system, i.e. biomass of these groups was higher at the end of simulations. This is explained by an easier escape for larger fish through the sorting grid than through the square mesh. The implementation of SM, on the other hand, would have a more positive impact on the small-sized demersal species (such as poor cod or juvenile hake).

\section{Changes in biomasses and catch}

Various target and non-target demersal species would benefit from the implementation of improved trawl selectivity (e.g. demersal fish mixed group, adult hake, and anglerfish). This is due to a decrease in fishing-induced mortality and an increase in some of their prey. For example, anglerfish would mainly benefit from an increase in demersal fish and invertebrates (Stergiou \& Karpouzi 2002).

Predicted decreases in the biomass of low TL organisms (e.g. suprabenthos, shrimps) can be explained by increasing predation; they are the main prey species of demersal fish, which benefit from improved selectivity (Stergiou \& Karpouzi 2002). Thus, although selectivity would favor them directly, this effect would be counteracted by the increase in predation mortality that would indirectly decrease their biomass, corresponding to trophic cascades occurring within the food web (Pace et al. 1999). This is also the case of commercially important species such as Norway lobster, blue whiting, and juvenile hake. Norway lobster is a secondary prey of anglerfish in the NW Mediterranean (Ríos 2000). If anglerfish benefit from an increase in prey availability and a decrease in fishing-induced mortality, there would be a consequent increase of predatory mortality in their prey (e.g. Norway lobster). The potential decrease in juvenile hake biomass is also due to increased predation by anglerfish and other demersal fish species (Ríos 2000, Stergiou \& Karpouzi 2002) and a decrease in benthic invertebrates, their main prey species (Bozzano et al. 2005).

Results for hake also suggest that these measures for increasing trawl selectivity may not be effective enough to allow a full recovery of highly exploited or overexploited species in the ecosystem. There is an increasing concern regarding growth and recruitment overfishing of hake in the Mediterranean Sea due to trawling and long-line activities (Aldebert \& Recasens 1996, Bas 2002). Adult hake, mainly caught by long line, were exposed to very high fishing mortality rates during the 1990s (Aldebert \& Recasens 1996, Coll et al. 2006). To facilitate the recovery of hake populations, selectivity of bottom-trawling (mainly capturing smaller individuals) should be improved to reduce immature catches, while fishing effort is reduced on adult individuals (mainly captured with long lines).

Improved trawl selectivity would have positive impacts on the catch of some target species (e.g. demersal fish mixed group, which includes species feeding on small demersal fish and crustaceans, mainly greater forkbeard and adult hake) in the trawl fishery, although the catches of some other species (e.g. Norway lobster, blue whiting, and juvenile hake) may slightly decrease if the present fishing effort were maintained. Because in the current trawl catches the mean length of hake is often $<20 \mathrm{~cm}$ (Bahamon et al. 2006, Sardà et al. 2006), i.e. below the minimum legal landing size, the decrease in catch of juvenile hake should not be seen as a negative result of increasing trawl selectivity. In the long run, the trawl fishery would benefit from an increased selectivity if the 
escaping hake survive. Moreover, an increase in trawl selectivity would offer advantages to long-line and bait troll fisheries in the area that target higher TL organisms (such as adult hake, Atlantic bonito, and bluefin tuna) and are more selective.

\section{Ecosystem indicators}

An increase in trawl selectivity would not only have an impact on demersal species but would also be noticeable in the pelagic compartments of the ecosystem. The significantly decreasing biomass of jellyfish and benthopelagic species shows indirect effects of increasing selectivity perceptible in the pelagic compartment due to the increase in predators and competitors (Coll et al. 2006). Both jellyfish and benthopelagic fishes have been proposed as indicators of ecosystem disruption due to overexploitation (Shannon et al. in press). Thus, results predicted from modeling suggest that more selective trawl fishing in the South Catalan Sea would have positive impacts at the ecosystem level due to indirect impacts mediated by the trophic web. Simulations also predict an increase (although nonsignificant) in the biomass of pelagic fishes. Since small and medium-sized pelagic fishes are also caught by trawls in the Catalan Sea, the observed increase is due to a small reduction on fishing pressure as well as a decrease in demersal predation (e.g. anglerfish, hake) produced by an increase in demersal prey. This is confirmed by a mixed trophic impact analysis (Ulanowicz \& Puccia 1990).

Different studies have shown how the development of fishing is frequently related to a decrease in the mean TL of the community, TLco, and of the mean TL of the catch, TLc (Pauly et al. 1998, Jennings et al. 2002). This was described for the Mediterranean Sea, although a much lower starting value of TLc was calculated compared to other marine areas of the world (Pauly et al. 1998). Our study suggests that the implementation of selectivity measures for trawling could contribute to a slight increase of the TLco in the South Catalan Sea, indicating an increase in biomass of high TL organisms in line with the significant increase in the $\mathrm{Q}^{\prime}$ index. Two situations would contribute to the increased TLco: (1) As fishing pressure on juveniles of commercial species is decreased, the biomass of exploited species is rebuilt to a certain level, and (2) by increasing trawl selectivity, fishing-induced mortality of small organisms decreases, and biomass of these species increases, so predators benefit from this situation. This would likely contribute to progress toward a higher sustainability of the fishing activity in the area (Tudela et al. 2005, Libralato et al. in press). However, our simulations indicate as well that total ecosystem biomass $\left(B_{t} / B_{0}\right)$ or total fishable biomass $\left(B f_{t} / B f_{0}\right)$ would not show significant changes due to enhanced selectivity alone. This highlights the need for a more drastic decrease in fishing effort in order to rebuild the South Catalan Sea ecosystem.

\section{Limitations of the analysis}

Here we assumed that fishing mortality reduction due to increased trawl selectivity is constant over the simulation period. However, modifying selectivity would change the demographic structure of the population, which in turn would modify the impact of the original selectivity measures on overall mortality. This limitation is also true for previous single-species selectivity assessments (e.g. Bahamon et al. 2007a,b) and ecosystem-based studies concerning the effects of improved selectivity scenarios (e.g. Kitchell et al. 2004, Criales-Hernandez et al. 2006). A more realistic study would require short-term monitoring of the fishing fleet activities and species dynamics in the ecosystem while selectivity measures are implemented. This would allow the description of dynamic fishing mortality rates that could be used to forecast ecosystem changes more accurately. Therefore, current results should be considered to be realistic only over a short time period. Moreover, we developed only simple Monte Carlo simulations and uncertainty analysis to assess ecosystem effects of selectivity scenarios in the South Catalan Sea. We encourage future investigations to further examine the effect of uncertainty of input parameters.

This study shows that data on post-escape mortality is important when assessing the ecosystem effects of improved trawl selectivity. However, very few data on escape-mortality are available for the Mediterranean Sea (Figuerola et al. 2001, Metin et al. 2004). Hence, the development of in situ studies under real commercial fishery conditions in the Mediterranean Sea for different selectivity devices and for different species is necessary. These studies should include assessments of the vulnerability of escapees to predation after the escape. Although habitat damage due to bottom-trawling could be important for some species and could mitigate positive impacts of increasing selectivity, data are scarce for this ecosystem and were not considered in our study.

Information on recruitment for most species in this ecosystem is still scarce; therefore, only information available on adult and juvenile hake was included in the ecosystem model (Coll et al. 2006). This limitation can be overcome as new ecological studies are developed. Meanwhile, our results could also be compared to singlespecies based modeling approaches (with higher resolu- 
tion on recruitment, but lower on community ecology) while performing similar management scenarios.

Further modeling efforts for the Catalan Sea should include the shallow coastal area (0 to $50 \mathrm{~m}$ depth, currently excluded from the model) so that the indirect ecological, social, and economical impact of trawl selectivity in artisanal fisheries due to selectivity changes in the continental shelf could be examined. Finally, including socioeconomic objectives should play an important role in assessing the benefits of selectivity enhancement under an Ecosystem Approach to Fisheries Management. Notwithstanding the obvious contribution of improved selectivity to increase the sustainability of the fishery, modification of gear or fishing methods to improve selectivity must be palatable to fishermen for it to be a suitable management option. Acceptance by fishermen of the modification of gear or fishing methods may benefit from accompanying measures to smooth the likely losses for the industry in the immediate short term.

\section{CONCLUSIONS}

This study highlights that the effects of increasing bottom trawl selectivity in the South Catalan Sea (NW Mediterranean) would be noticeable at the ecosystem level, for both commercial and non-commercial demersal species and also in the pelagic compartment. This is due to the complexity of trophic interactions and the direct and indirect impacts induced by fishing and mediated by the trophic web. These results have direct management applications giving support to the implementation of an improved selectivity of the bottomtrawling fleet in the area from a biological point of view. This measure would certainty contribute toward ecosystem-based management of fisheries in the NW Mediterranean region. However, a drastic reduction of fishing effort in parallel with a greater increase in gear selectivity would be necessary for the recovery of highly exploited or overexploited demersal species and the ecosystem.

Acknowledgements. We acknowledge all colleagues who provided data and technical advice for the development of the ecological model and helped during the field work in the South Catalan Sea. We also acknowledge Dr. E.B. Morello for helpful comments on the manuscript and Dr. L.J. Shannon and 2 other anonymous reviewers for very useful corrections. This work was developed within the context of the NECESSITY project (SSP8-CT-2003, 50/605). During the work, M.C. was supported financially by the Catalan Government through the Consolidated Research Group budget.

\section{LITERATURE CITED}

Aldebert Y, Recasens L (1996) Comparison of methods for stock assessment of European hake Merluccius merluc- cius in the gulf of Lions (Northwestern Mediterranean). Aquat Living Resour 9:13-22

Bahamon N, Sardà F, Suuronen P (2006) Improvement of trawl selectivity in the Mediterranean demersal fishery by using a $40 \mathrm{~mm}$ square mesh codend. Fish Res 81:15-25

Bahamon N, Sardà F, Suuronen P (2007a) Potential benefits from improved selectivity in the northwest Mediterranean multispecies trawl fishery. ICES J Mar Sci 64:757-760

Bahamon N, Sardà F, Suuronen P (2007b) Selectivity of flexible size-sorting grid in Mediterranean multispecies trawl fishery. Fish Sci: 73:1231-1240

Bas C (2002) El mar Mediterráneo: recursos vivos y explotación. Ariel Ciencia, Barcelona

Bax NJ (1991) A comparison of the fish biomass flow to fish, fisheries and mammals in six marine ecosystems. ICES Mar Sci Symp 193:217-224

Bozzano A, Sardà F, Ríos J (2005) Vertical distribution and feeding patterns of the juvenile European hake, Merluccius merluccius in the NW Mediterranean. Fish Res 73: 29-36

Browman HI, Stergiou KI (2004) Perspectives on ecosystembased approaches to the management of marine resources. Mar Ecol Prog Ser 274:269-303

Calderon-Aguilera LE (1991) An autoregressive model of the temperature-growth relationship for the Western Mediterranean blue whiting Micromesistius poutassou. Ecol Model 56:47-61

Campillo A (1992) Les pêcheries françaises de Méditerranée: synthèse des connaissances. Institut Francais de Recherche pour l'Exploitation de la Mer

Christensen V, Walters C (2004a) Ecopath with Ecosim: methods, capabilities and limitations. Ecol Model 172:109-139

Christensen V, Walters C (2004b) Trade-offs in ecosystemscale optimization of fisheries management policies. Bull Mar Sci 74:549-562

Christensen V, Walters C, Pauly D (2005) Ecopath with Ecosim: a user's guide. Fisheries Centre of University of British Columbia, Vancouver

Coll M, Palomera I, Tudela S, Sardà F (2005) Assessing the impact of fishing activities and environmental forcing on a Northwestern Mediterranean ecosystem along the last decades of intense exploitation. Adv Mar Ecosyst Model Res Int Symp at Plymouth Marine Laboratory, 27 to 29 June 2005, Plymouth

Coll M, Palomera I, Tudela S, Sardà F (2006) Trophic flows, ecosystem structure and fishing impacts in the South Catalan Sea, Northwestern Mediterranean. J Mar Syst 59: 63-96

Coll M, Santojanni A, Arneri E, Palomera I, Tudela S (2007) An ecosystem model of the Northern and Central Adriatic Sea: analysis of ecosystem structure and fishing impacts. J Mar Syst 67:119-154

> Criales-Hernandez MI, Duarte LO, García CB, Manjarrés L (2006) Ecosystem impacts of introduction of bycatch reduction devices in a tropical shrimp trawl fishery: insights through simulation. Fish Res 77:333-342

Cury P, Shannon LJ, Shin YJ (2003) The functioning of marine ecosystems: a fisheries perspective. In: Sinclair M, Valdimarsson G (eds) Responsible fisheries in the marine ecosystem. FAO and CAB International, Wallingford, p 103-123

Díaz JI, Nelson CH, Barber JH, Giro S (1990) Late Pleistocene and Holocene sedimentary facies in the Ebro continental shelf. Mar Geol 95:333-352

Estrada M (1996) Primary production in the Northwestern Mediterranean. Sci Mar 60 (Suppl 2):55-64

Farmer MJ, Brewer DT, Blaber SJM (1998) Damage to selected fish species escaping from prawn trawl codends: 
a comparison between square-mesh and diamond-mesh. Fish Res 38:73-81

Figuerola P, Sánchez P, Demestre M (2001) Preliminary results on megafauna variations due to experimental trawling disturbance. Rapp Comm Int Mer Médit 36:265

Froese R, Pauly D (eds) (2005) FishBase. www.fishbase.org

Fulton EA, Smith ADM (2004) Lessons learnt from a comparison of three ecosystem models for Port Phillip Bay, Australia. Afr J Mar Sci 26:219-243

Ingolfsson O, Soldal AV, Huse I (2002) Mortality and injuries of haddock, cod and saithe escaping through codend meshes and sorting grids. ICES CM 2002/V:32.

Jennings S, Greenstreet SPR, Hill L, Piet GJ, Pinnegar JK, Warr KL (2002) Long-term trends in the trophic structure of the North Sea fish community: evidence from stableisotope analysis, size-spectra and community metrics. Mar Biol 141:1085-1097

Jonsson E (1994) Scale damage and survival of haddock escaping through codend meshes (a tank experiment). ICES CM 1994/B:16

Kempton RA, Taylor LR (1976) Models and statistics for species diversity. Nature 262:818-820

Kitchell JF, Kaplan IC, Cox SP, Martell SJD, Essington TE, Boggs CH, Walters C (2004) Ecological and economic components of alternative fishing methods to reduce bycatch of marlin in a tropical pelagic ecosystem. Bull Mar Sci 74:607-619

Libralato S, Coll M, Tudela S, Palomera I, Pranovi F (2008) Novel index for quantification of ecosystem effects of fisheries as removal of secondary production. Mar Ecol Prog Ser 355:107-129

Lleonart J, Salat J (1997) VIT: Software for fishery analysis. User's manual. FAO Computerised Information Series (Fisheries), No. 11, FAO, Rome,

Merella P, Quetglas A, Alemany F, Carbonell A (1997) Length-weight relationship of fishes and cephalopods from the Balearic Islands (western Mediterranean). Naga ICLARM Q 20:66-68

Metin C, Tokac A, Ulas A, Düzbastilar FO and 6 others (2004) Survival of red mullet (Mullus barbatus L. 1758) after escape from a trawl codend in the Aegean Sea. Fish Res 70:49-53

Pace ML, Cole JJ, Carpenter SR, Kitchell JF (1999) Trophic cascades revealed in diverse ecosystems. Trends Ecol Evol $14: 483-488$

Palomera I (1992) Spawning of anchovy Engraulis encrasicolus in the northwestern Mediterranean relative to hydrographic features in the region. Mar Ecol Prog Ser 79: 215-223

Pauly D, Christensen V, Dalsgaard J, Froese R, Torres FJ (1998) Fishing down marine food webs. Science 279: 860-863

Pikitch E, Erickson D, Suuronen P, Lehtonen E, Rose C, Bublitz C (2002) Mortality of walleye pollock escaping from the codend and intermediate (= extension) section of a pelagic trawl. ICES CM 2002/V:15

Politou CY, Papaconstantinou C (1991) Population biology of Trisopterus minutus capelanus (Gadidae) from the Eastern coast of Greece. Cybium 15:69-81

Recasens L, Lombarte A, Morales-Nin B, Torres GJ (1998) Spatiotemporal variation in the population structure of the European hake in the NW Mediterranean. J Fish Biol 53: $387-401$

Ríos J (2000) Feeding habits and trophic relationships in a demersal fish community in the Catalan sea (western Mediterranean). MSc thesis, University of Wales, Bangor

Sangster GI, Lehmann KM, Breen M (1996) Commercial fishing experiments to assess the survival of haddock and whiting after escape from four sizes of diamond mesh codends. Fish Res 25:323-345
Sardà F, Lleonart J, Cartes JE (1998) An analysis of the population dynamics of Nephrops norvegicus (L) in the Mediterranean Sea. Sci Mar 62 (Suppl 1):135-143

Sardà F, Bahamon N, Sardà-Palomera F, Molí B (2005) Commercial testing of a sorting grid to reduce catches of juvenile hake (Merluccius merluccius, L.) in the western Mediterranean demersal trawl fishery. Aquat Living Resour 18:87-91

Sardà F, Bahamon N, Molí B, Sardà-Palomera F (2006) The use of a square mesh codend and sorting grids to reduce catches of young fish and improve sustainability in a multispecies bottom trawl fishery in the Mediterranean. Sci Mar 70:347-353

Shannon LJ, Coll M, Neira S, Cury P, Roux JP (in press) Role of small pelagic fish on the ecosystem. In: Checkley DM, Roy C, Alheit J, Oozeki Y (eds) Climate change and small pelagic fish. Cambridge University Press, Cambridge

Soldal AV, Engaas A (1997) Survival of young gadoids excluded from a shrimp trawl by a rigid deflecting grid. ICES J Mar Sci 54:117-124

Soldal AV, Engaas A, Isaksen B (1993) Survival of gadoids that escape from demersal trawl. ICES Mar Sci Symp 196: $122-127$

Stergiou KI, Karpouzi V (2002) Feeding habits and trophic levels of Mediterranean fish. Rev Fish Biol Fish 11: 217-254

Suuronen P (1991) The effects of a rigid grating on the selection and survival of Baltic herring - preliminary results. ICES CM 1991/B:17

Suuronen P (2005) Mortality of fish escaping trawl gears. FAO Fish Tech Pap 478

Suuronen P, Lehtonen E, Tschernij V, Orrensalo A (1993) Survival of Baltic herring (Clupea harengus L.) escaping from a trawl codend and through a rigid sorting grid. ICES CM 1993/B:14

Suuronen P, Turunen T, Kiviniemi M, Karjalainen J (1995) Survival of vendace (Coregonus albula) escaping from a trawl cod end. Can J Fish Aquat Sci 52:2527-2533

Suuronen P, Erickson DL, Orrensalo A (1996a) Mortality of herring escaping from pelagic trawl codends. Fish Res 25: 305-321

Suuronen P, Perez-Comas JA, Lehtonen E, Tschernij V (1996b) Size-related mortality of herring (Clupea harengus L.) escaping through a rigid sorting grid and trawl codend meshes. ICES J Mar Sci 53:691-700

Suuronen P, Lehtonen E, Tschernij V, Larsson PO (1996c) Skin injury and mortality of Baltic cod escaping from two codends equipped with exit windows. Arch Mar Fish Res 44:165-178

Suuronen P, Lehtonen E, Jounela P (2005) Escape mortality of trawl caught Baltic cod (Gadus morhua) - the effect of water temperature, fish size and codend catch. Fish Res 71: 151-163

Tudela S, Coll M, Palomera I (2005) Developing an operational reference framework for fisheries management based on a two dimensional index on ecosystem impact. ICES J Mar Sci 62:585-591

Ulanowicz RE, Puccia CJ (1990) Mixed trophic impacts in ecosystems. Coenoses 5:7-16

van Beek FA, van Leeuwen PI, Rijnsdorp AD (1990) On the survival of plaice and sole discards in the otter-trawl and beam-trawl fisheries in the North Sea. Neth J Sea Res 26: 151-160

Wileman DA, Ferro RST, Fonteyne R, Millar RB (1996) Manual of methods of measuring the selectivity of towed fishing gears. ICES Coop Res Rep 215, Copenhagen 
Appendix 1. Reviewed data used to estimate the increase in mortality by species due to the escape from trawl gears

\begin{tabular}{|c|c|c|c|c|c|c|c|c|}
\hline Species & Ecosystem & Year & Sizes/ages & $\begin{array}{l}\text { Mortality } \\
\text { rates (\%) }\end{array}$ & $\begin{array}{l}\text { Selectivity } \\
\text { device }\end{array}$ & $\begin{array}{l}\text { Water } \\
\text { emperature } \\
\left({ }^{\circ} \mathrm{C}\right)\end{array}$ & Source & Observations \\
\hline \multicolumn{9}{|l|}{ Mediterranean } \\
\hline Gobius niger & Catalan Sea & 1997 & $\begin{array}{l}\text { Small and } \\
\text { large }\end{array}$ & 88.90 & $\begin{array}{l}40 \mathrm{~mm} \\
\text { diamond mesh }\end{array}$ & & $\begin{array}{l}\text { Figuerola } \\
\text { et al. (2001) }\end{array}$ & \\
\hline Solea vulgaris & Catalan Sea & 1997 & & 28.60 & & & & \\
\hline $\begin{array}{l}\text { Liocarcinus } \\
\text { depurator }\end{array}$ & Catalan Sea & 1997 & & 14.30 & & & & \\
\hline Medoripe lanata & Catalan Sea & 1997 & & 0 & & & & \\
\hline Mullus barbatus & Aegean Sea & $\begin{array}{c}\text { September } \\
2001\end{array}$ & $7-17 \mathrm{~cm}$ & 7 & $\begin{array}{l}40 \mathrm{~mm} \\
\text { diamond mesh }\end{array}$ & $24.5-25.5$ & $\begin{array}{l}\text { Metin } \\
\text { et al. (2004) }\end{array}$ & $\begin{array}{l}\text { Dead fish smaller than } \\
\text { survivors. } \\
\text { Majority of deaths } \\
\text { occurred in the first } 24 \mathrm{~h}\end{array}$ \\
\hline \multicolumn{9}{|l|}{ Other areas } \\
\hline Solea solea & North Sea & & & 40 & $\begin{array}{l}\text { Beam trawl } \\
\text { vessel }\end{array}$ & & $\begin{array}{l}\text { van Beek } \\
\text { et al. (1990) }\end{array}$ & \\
\hline $\begin{array}{l}\text { Pleuronectes } \\
\text { platessa }\end{array}$ & North Sea & & & & & & & \\
\hline Clupea harengus & Baltic Sea & $\begin{array}{l}\text { Spring } \\
1991\end{array}$ & $\begin{array}{l}\text { Small and } \\
\text { large }\end{array}$ & $7-84$ & $\begin{array}{l}\text { Rigid grid, } \\
14 \mathrm{~mm} \text { spacing }\end{array}$ & & $\begin{array}{l}\text { Suuronen } \\
(1991)\end{array}$ & \\
\hline Pollachius virens & Experimental & & & 10 & & & $\begin{array}{l}\text { Soldal } \\
\text { et al. (1993) }\end{array}$ & \\
\hline Gadus morhua & Experimental & & & 0 & & & & \\
\hline $\begin{array}{l}\text { Melanogrammus } \\
\text { aeglefinus }\end{array}$ & Experimental & & & 20 & & & & \\
\hline Clupea harengus & $\begin{array}{l}\text { Northern } \\
\text { Baltic Sea }\end{array}$ & $\begin{array}{l}\text { May-June } \\
1993\end{array}$ & $8-17 \mathrm{~cm}$ & $\begin{array}{l}85-90 \\
75-85\end{array}$ & $\begin{array}{l}36 \mathrm{~mm} \text { diamond- } \\
\text { mesh cod end } \\
\text { Rigid sorting grid, } \\
12 \mathrm{~mm} \text { bar spacing }\end{array}$ & & $\begin{array}{l}\text { Suuronen } \\
\text { et al. (1993) }\end{array}$ & \\
\hline $\begin{array}{l}\text { Melanogrammus } \\
\text { aeglefinus }\end{array}$ & Experimental & & & $50-70$ & $\begin{array}{l}155 \mathrm{~mm} \text { diamond } \\
\text { mesh }\end{array}$ & & $\begin{array}{c}\text { Jonsson } \\
(1994)\end{array}$ & \\
\hline Coregonus albula & $\begin{array}{l}\text { Lake } \\
\text { Puulavesi }\end{array}$ & $\begin{array}{c}\text { July-August } \\
1993\end{array}$ & $5-10 \mathrm{~cm}$ & $30-40$ & $\begin{array}{l}24 \mathrm{~mm} \text { square- } \\
\text { mesh trawl }\end{array}$ & $13-20$ & $\begin{array}{l}\text { Suuronen } \\
\text { et al. (1995) }\end{array}$ & \\
\hline $\begin{array}{l}\text { Merlanogrammus } \\
\text { aeglifinus }\end{array}$ & $\begin{array}{l}\text { NW coast } \\
\text { of Scotland }\end{array}$ & $\begin{array}{c}\text { Summer } \\
1993\end{array}$ & $16-37 \mathrm{~cm}$ & $\begin{array}{l}33-52 \\
18-21 \\
22-27 \\
11-15\end{array}$ & $\begin{array}{l}70 \mathrm{~mm} \text { diamond- } \\
\text { mesh cod end } \\
90 \mathrm{~mm} \text { diamond- } \\
\text { mesh cod end } \\
100 \mathrm{~mm} \text { diamond- } \\
\text { mesh cod end } \\
110 \mathrm{~mm} \text { diamond- } \\
\text { mesh cod end }\end{array}$ & & $\begin{array}{l}\text { Sangster } \\
\text { et al. (1996) }\end{array}$ & $\begin{array}{l}\text { Smaller fishes showed } \\
\text { higher mortalities }\end{array}$ \\
\hline $\begin{array}{l}\text { Merlangius } \\
\text { merlangus }\end{array}$ & $\begin{array}{l}\text { NW coast } \\
\text { of Scotland }\end{array}$ & $\begin{array}{l}\text { Summer } \\
1993\end{array}$ & $17-36 \mathrm{~cm}$ & $\begin{array}{l}40-48 \\
22-27 \\
23-33 \\
14-17\end{array}$ & $\begin{array}{l}70 \mathrm{~mm} \text { diamond- } \\
\text { mesh cod end } \\
90 \mathrm{~mm} \text { diamond- } \\
\text { mesh cod end } \\
100 \mathrm{~mm} \text { diamond- } \\
\text { mesh cod end } \\
110 \mathrm{~mm} \text { diamond- } \\
\text { mesh cod end }\end{array}$ & & & $\begin{array}{l}\text { Smaller fishes showed } \\
\text { higher mortalities }\end{array}$ \\
\hline Clupea harengus & $\begin{array}{l}\text { Northern } \\
\text { Baltic Sea }\end{array}$ & $\begin{array}{l}\text { April-June } \\
1992\end{array}$ & $\begin{array}{l}<12 \mathrm{~cm} \\
12-17 \mathrm{~cm}\end{array}$ & $\begin{array}{l}72-91 \\
30-62\end{array}$ & $\begin{array}{l}\text { Diamond-mesh of } \\
26 \text { and } 36 \mathrm{~mm} \\
\text { Diamond-mesh of } \\
26 \text { and } 36 \mathrm{~mm}\end{array}$ & $5-10$ & $\begin{array}{l}\text { Suuronen } \\
\text { et al. (1996a) }\end{array}$ & $\begin{array}{l}\text { Mortality was highly } \\
\text { size-dependent }\end{array}$ \\
\hline
\end{tabular}


Appendix 1. (continued)

\begin{tabular}{|c|c|c|c|c|c|c|c|c|}
\hline \multirow{2}{*}{ Clupea harengus } & & $\begin{array}{l}\text { October- } \\
\text { November }\end{array}$ & $12-17 \mathrm{~cm}$ & $44-77$ & $\begin{array}{l}\text { Rigid sorting grid, } \\
12 \mathrm{~mm} \text { bar spacing }\end{array}$ & & & \\
\hline & & & $12-17 \mathrm{~cm}$ & $83-100$ & $\begin{array}{l}36 \text { mm diamond- } \\
\text { mesh cod end }\end{array}$ & & & \\
\hline Gadus morhua & $\begin{array}{l}\text { Southern } \\
\text { Baltic sea }\end{array}$ & $\begin{array}{c}\text { May-June } \\
1994\end{array}$ & $24-50 \mathrm{~cm}$ & $<1$ & $\begin{array}{l}95 \mathrm{~mm} \text { exit } \\
\text { windows }\end{array}$ & 9.5 & $\begin{array}{l}\text { Suuronen } \\
\text { et al. (1996c) }\end{array}$ & \\
\hline Gadus morhua & $\begin{array}{l}\text { Northern } \\
\text { Norway }\end{array}$ & 1993-1994 & $\begin{array}{l}1 \mathrm{yr} \\
\text { old }\end{array}$ & Minimal & $\begin{array}{l}\text { Diagonal } \\
\text { metal grid }\end{array}$ & $4-6$ & $\begin{array}{l}\text { Soldal \& } \\
\text { Engaas (1997) }\end{array}$ & \\
\hline Various fishes & $\begin{array}{l}\text { Gulf of } \\
\text { Carpentaria }\end{array}$ & $\begin{array}{c}\text { November } \\
1993\end{array}$ & & $\begin{array}{l}\text { Higher } \\
\text { Higher } \\
\text { Minimal }\end{array}$ & $\begin{array}{l}\text { Diamond-mesh } \\
\text { cod end, } 45 \mathrm{~mm} \\
\text { Square mesh } \\
\text { of } 38 \mathrm{~mm} \\
\text { Square mesh } \\
\text { of } 45 \mathrm{~mm}\end{array}$ & & $\begin{array}{l}\text { Farmer } \\
\text { et al. (1998) }\end{array}$ & $\begin{array}{l}\text { Study conducted in terms } \\
\text { of mechanical damage } \\
\text { Species studied: } \\
\text { Sardinella albella, } \\
\text { Saurida micropectoralis, } \\
\text { Arius thalassinus, } \\
\text { Apogon poecilopterus, } \\
\text { Carax bucculentus, } \\
\text { Leiognathus splendens, } \\
\text { Lutjanus malabaricus, } \\
\text { Pomadasys maculatum, } \\
\text { Upeneus sulphureus, } \\
\text { Pseudorhombus arsius }\end{array}$ \\
\hline Gadus morhua & $\begin{array}{l}\text { Baltic } \\
\text { Sea }\end{array}$ & $1997-1998$ & $12-45 \mathrm{~cm}$ & $>3$ & & $<10$ & $\begin{array}{l}\text { Suuronen } \\
\text { et al. (2005) }\end{array}$ & $\begin{array}{l}120 \mathrm{~mm} \text { diamond-mesh } \\
\text { cod end, Danish type } \\
105 \mathrm{~mm} \text { escape-window } \\
\text { cod end, } 105 \mathrm{~mm} \text { square- } \\
\text { mesh top-panel cod end }\end{array}$ \\
\hline
\end{tabular}

Editorial responsibility: Konstantinos Stergiou, Thessaloniki, Greece
Submitted: February 5, 2007; Accepted: July 29, 2007

Proofs received from author(s): January 28, 2008 